\title{
The origins and evolution of Cypriot glazed ware productions during the thirteenth to seventeenth centuries CE
}

\author{
Carmen Ting $^{1}\left(\mathbb{D} \cdot\right.$ Thilo Rehren $^{2,3} \cdot$ Athanasios Vionis $^{4} \cdot$ Vasiliki Kassianidou $^{4}$
}

Received: 3 October 2020 / Accepted: 29 December 2020 / Published online: 30 January 2021

(C) The Author(s) 2021

\begin{abstract}
This paper challenges the conventional characterisation of glazed ware productions in the eastern Mediterranean, especially the ones which did not feature the use of opaque or tin-glazed technology, as technologically stagnant and unsusceptible to broader socio-economic developments from the late medieval period onwards. Focusing on the Cypriot example, we devise a new approach that combines scientific analyses (thin-section petrography and SEM-EDS) and a full consideration of the chaine opératoire in context to highlight the changes in technology and craft organisation of glazed ware productions concentrating in the Paphos, Famagusta and Lapithos region during the thirteenth to seventeenth centuries CE. Our results indicate that the Paphos production was short-lived, lasting from the establishment of Frankish rule in Cyprus in the thirteenth century to the aftermath of the fall of the Crusader campaigns in the fourteenth century. However, glazed ware production continued in Famagusta and Lapithos from the late thirteenth/fourteenth centuries through to the seventeenth century, using technical practices that were evidently different from the Paphos production. It is possible that these productions were set up to serve the new, local demands deriving from an intensification of commercial activities on the island. Further changes occurred to the technical practices of the Famagusta and Lapithos productions around the 16th/17th centuries, coinciding with the displacement of populations and socio-political organisation brought by the Ottoman rule.
\end{abstract}

Keywords Glaze technology $\cdot$ Cyprus $\cdot$ Eastern Mediterranean $\cdot$ Late medieval $\cdot$ Post-medieval

\section{Introduction}

During the medieval and post-medieval periods, glazed wares became an integral component of material culture in the eastern Mediterranean, marking the beginning of their transition to become a global phenomenon, with lasting impacts on our consumption habits until today. The extant understanding of the processes and mechanisms leading to this important episode of technological and social changes remains very patchy.

Carmen Ting

carmen.k.ting@gmail.com

1 McDonald Institute for Archaeological Research, University of Cambridge, Cambridge, UK

2 Science and Technology in Archaeology and Culture Research Centre, The Cyprus Institute, Nicosia, Cyprus

3 UCL Institute of Archaeology, London WC1H, OPY, UK

4 Archaeological Research Unit, Department of History and Archaeology, University of Cyprus, Nicosia, Cyprus
The Islamic opaque or tin-glazed wares - described to be the 'elite' and 'first quality' ceramics that were only produced in a few places and circulated over a broad geographical distance (Mason 1997: 171) — have been the focus of much research in the past and present alike, reigniting the debate on their origins and technological evolutions (e.g. Mason and Tite 1997; Matin et al. 2018; Salinas et al. 2019; Tite et al. 2015; Watson 2014). In contrast, the glazed wares that do not have opaque glazes have received much less attention, as it is assumed that they were mostly produced and consumed locally and/or distributed to places not far from their origins of production, with their technology and craft organisation being static and unsusceptible to socio-economic developments (Armstrong et al. 1997; Mason 1997: 171-72). This view is being challenged, with the recent examination of materials from Corinth as one of the notable examples, showing that distinct technologies were used to produce lead glazes corresponding to the changing political situation of Byzantium (Palamara et al. 2016; White 2009). In spite of these efforts, very little is still known about how glazed ware productions, especially non-opacified, emerged and developed, even 
though they constitute the bulk of glazed ceramic evidence in the archaeological record.

A case in point is the Cypriot production of glazed tablewares, which only began in the thirteenth century $\mathrm{CE}$. These productions are poorly understood, as previous research centred on their styles (e.g. du Plat-Taylor and Megaw 1951; Papanikola-Bakirtzi 1989, 1996, 2004, 2012; Vallauri and François 2010; von Wartburg 1997; Waksman and von Wartburg 2006), while technical studies are few and narrowly focused (e.g. Charalambous et al. 2010, 2012, 2014; Waksman 2014). Against this background, we developed a more holistic, interdisciplinary research framework that combines stylistic and scientific analyses with a consideration of the full chaine opératoire in context. Our work sought to identify and characterise the Cypriot productions from their emergence to the seventeenth century $\mathrm{CE}$, as a starting point to explore the processes and mechanisms that contributed to the proliferation of glazed ware productions more generally in the eastern Mediterranean. Owing to its particular position connecting Europe with the Middle East, Cyprus is a vivid reflection of the broader atmosphere in the Mediterranean at the time, marked by constant conflicts between Christian West and Islamic East, intertwined with competitions among merchant powers (Hunt 2014).

\section{Materials}

We selected 60 glazed ware samples from excavations at the sites of Agios Georgios Hill and Vitonos Street (both within the modern city of Nicosia) and at the Hellenistic-Roman theatre in Paphos (Paphos Theatre), and from archaeological surveys in the area near the modern villages of Kofinou and PotamiaAyios Sozomenos (Figs. 1 and 2). The excavations and surveys at these sites yielded substantial evidence of late medieval and post-medieval occupation, as seen in the recovery of a wide range of glazed ware types belonging to the productions from different sites within Cyprus and the imported ones (Cook 2004; Cook and Green 2002; François and Vallauri 2001; Lécuyer and Michaelides 2004; Lécuyer et al. 2002; Papantoniou and Vionis 2018; Pilides 2003; Pilides et al. 2010; Vallauri 2004; Vionis 2018). We focused on the ones that are considered to be representative of the local ceramic repertoires dating to different phases between the 13th and 17th centuries based on morphostylistic analyses, including slip-painted, plain glazed, sgraffito, sgraffito with slip-painted decoration, painted glazed, and whiteslipped glazed wares (Table 1).

Samples from Kofinou come from the survey around the church of Panagia in the Xeros River valley (Larnaca district), where surface ceramic evidence points to a large post-Roman rural settlement of approximately 10 ha that survived from the beginning of the thirteenth to the seventeenth/eighteenth centuries $\mathrm{CE}$; here, glazed wares representing $5 \%$ of the assemblage from the site (Papantoniou and Vionis 2018: 20). Similarly, the samples from Potamia-Ayios Sozomenos come from rural sites in the territory of the present-day administrative district of Nicosia, dated to the fourteenth to sixteenth/seventeenth centuries (François and Vallauri 2001, 2014), comprising characteristic examples of glazed tableware commonly found in both urban and rural contexts. The samples from the urban centres of modern Nicosia (Agios Georgios Hill and Vitonos Street) provide, once again, interesting comparanda for the typical local ceramic repertoire dating to the period between the thirteenth and seventeenth centuries. The material from those two sites (currently under systematic study by S. Gabrieli) is not yet published. The Paphos Theatre assemblage is an exception, with the glazed wares and direct evidence of production such as tripod stilts and clay lumps being found in a sealed deposit securely dated to the thirteenth century (Barker 2016; Green et al. 2011, 2014); thus a more comprehensive set of samples from this assemblage was studied first (Ting et al. 2019).

The dating of the samples from the abovementioned sites was carried out on the basis of their similarity in terms of fabric (macroscopic examination), shape and decorative style to published examples from excavated and confirmed production sites on the island, namely Paphos, Lemba, Lapithos and Nicosia (Charalambous 2014; Charalambous et al. 2010; Cook 2014; Papanikola-Bakirtzi 1989, 1996, 2004, 2019; Taylor and Megaw 1951; Ting et al. 2019). Cypriot glazed production has so far been classified (and dated) according to decorative style, such as slip-painted, plain glazed, sgraffito, sgraffito with slip-painted decoration, painted glazed and white-slipped glazed wares (for the chronology of these wares, see Taylor and Megaw 1951: 1-13; Papanikola-Bakirtzi 1996: 60, 7374, 84-85, 99, 115, 131, 145, 172-173, 187-188, 196), all represented in our samples. Despite the bias in our sampling, with a slightly greater proportion of samples from the Paphos Theatre assemblage, the samples should allow for a better understanding of the temporal developments of technical practices characteristic of different productions.

\section{Methods}

\section{The chaîne opératoire approach to glazed ware production}

The production of glazed wares involves a complex process (Fig. 3), each step revealing manufacturing choices and allowing room for variables (Gosselain 1998; Lemonnier 1992). Reconstructing the technical practices characteristic of production through time permits a more nuanced perspective of diachronic development, highlighting the decisions made by potters. Examining the technical practices across productions allows a more sophisticated comparison of behavioural influences than those afforded by traditional 'stylistic' 


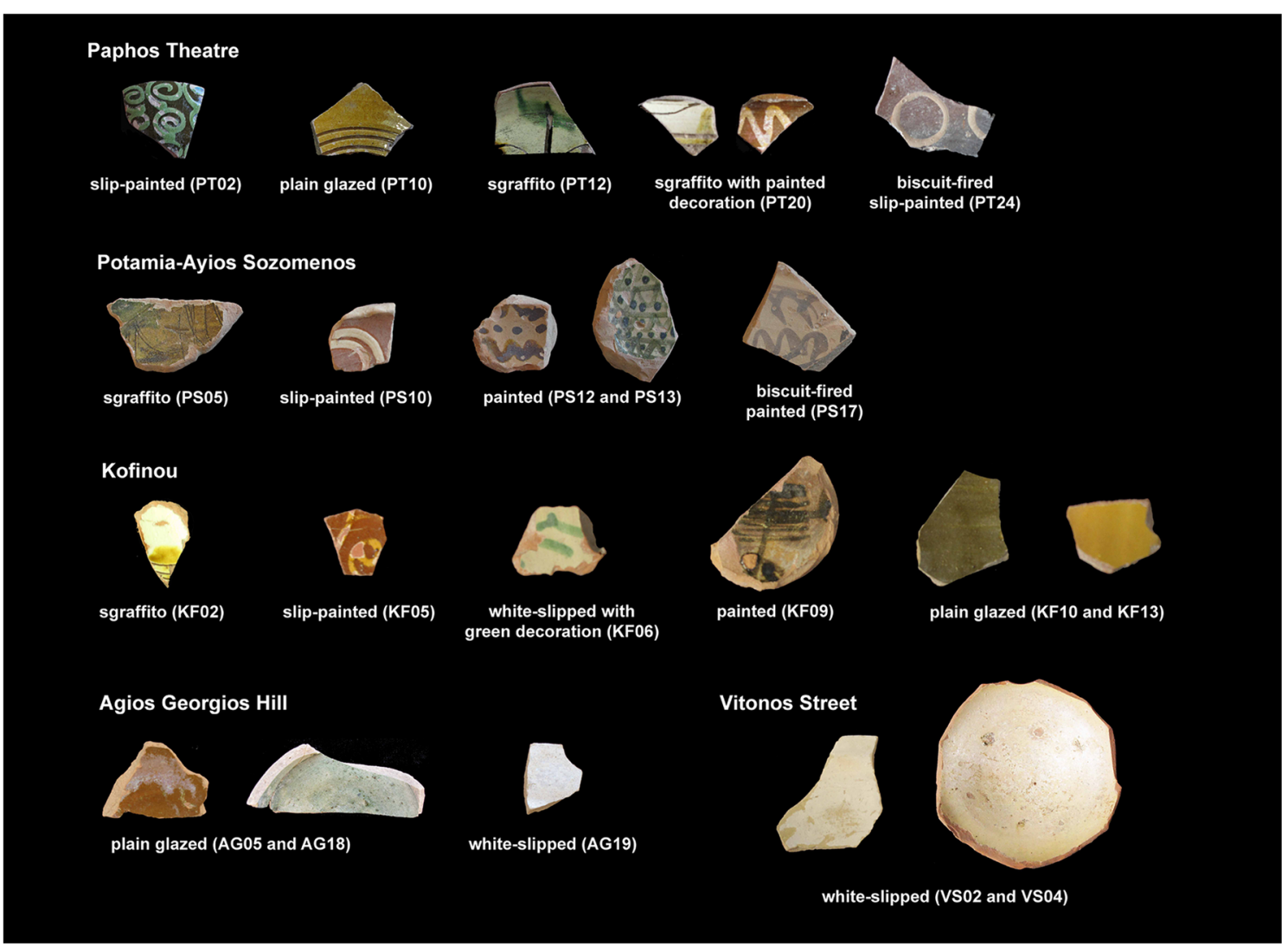

Fig. 1 Selected glazed ware samples that are representative of each site. Reproduced at different scales

affiliation, which has perhaps overplayed the 'imitation' dimensions rather than the active dynamics through which knowledge was transferred among potters and beyond.

\section{Thin-section petrography}

The potential provenance of the samples was determined by comparing their mineralogy with the geology of the different regions described in geological maps and surveys. Thin-section petrography was used to record the mineralogical and textural variations that exist among the samples and to characterise the recipe of the ceramic body, informing about paste preparation methods. All samples were prepared into thin sections at the UCL Wolfson Archaeological Sciences Laboratories and analysed using a LEICA DM EP Polarization Microscope. In the description of the petrographic observation, the percentage charts developed by Matthews et al. (1991) were used to estimate the relative abundance of inclusions.

\section{Scanning electron microscope energy dispersive spectrometry (SEM-EDS)}

The recipes of the paints, slips and glazes and the method and order of their application for all samples were identified using SEM-EDS. Two SEM-EDS suites - a JEOL JSM 6610 low vacuum SEM at the UCL Qatar Archaeological Material
Sciences Laboratories, and a ZEISS EVO25 at the UCL Institute of Archaeology Wolfson Archaeological Sciences Laboratories-were used. Both suites were fitted with the Oxford Instruments Aztec EDS analysis system. The JEOL JSM 6610 was set to $20.0 \mathrm{kV}$ accelerating voltage and took about 22 to $25 \mathrm{~s}$ total per measurement, whereas the ZEISS EVO 25 was set to $20.0 \mathrm{kV}$ accelerating voltage and collected about 750,000 X-rays, which also took about 22 to $25 \mathrm{~s}$ total per measurement. Corning Glass $\mathrm{C}$ was analysed as reference material at the beginning of each analytical session. Comparing with the published values, the absolute and relative errors document the accuracy of the measurements, showing that all elements but $\mathrm{P}_{2} \mathrm{O}_{5}$ and $\mathrm{SnO}_{2}$ are within $10 \%$ of the expected values. The mean and standard deviation values highlight the reproducibility of data for both SEM suites, while the mean values of the measurements generated by the two SEM suites document the cross-instrument data consistency (Supplementary Table S1). A fused basalt sample (BCR-2) was also analysed by the ZEISS EVO 25 as an extra standard for ceramic materials. A cobalt standard was analysed at regular intervals to monitor the beam current stability.

The area of analysis for the slip, paint and glaze was set around $25 \times 50 \mu \mathrm{m}$ for areas that contain particles and newly formed crystal phases, and to $10 \times 10 \mu \mathrm{m}$ for areas avoiding these features. The area of analysis for the ceramic body was set around $150 \times 300 \mu \mathrm{m}$ at low magnification. We acknowledge 


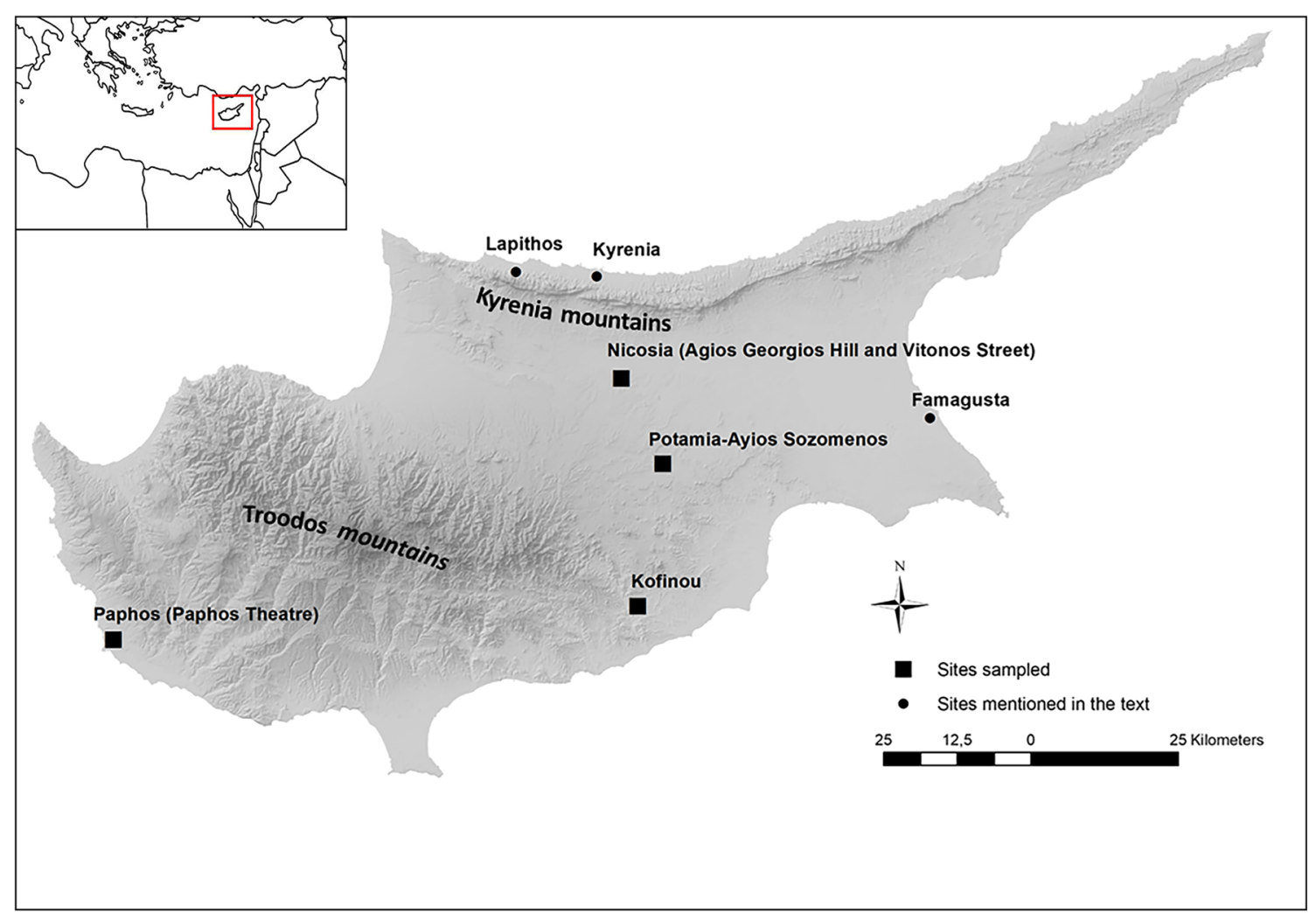

Fig. 2 Map of Cyprus showing the sites mentioned in the text, produced with the digital geological data provided by the Cyprus Geological Survey. The DMS coordinates of the excavated sites are $35^{\circ} 09^{\prime} 58.8^{\prime \prime}$ $\mathrm{N}$ and $33^{\circ} 21^{\prime} 18.9^{\prime \prime} \mathrm{E}$ for Agios Georgios Hill, $35^{\circ} 10^{\prime} 13.9^{\prime \prime} \mathrm{N}$ and $33^{\circ}$ $22^{\prime} 15.6^{\prime \prime} \mathrm{E}$ for Vitonos Street and $34^{\circ} 45^{\prime} 39.50^{\prime \prime} \mathrm{N}$ and $32^{\circ} 24^{\prime} 51.27^{\prime \prime} \mathrm{E}$ for Paphos Theatre. Noteworthy is that Agios Georgios Hill and Vitonos Street are represented in the map as 'Nicosia', given the close proximity of these two sites. The DMS coordinates of the surveyed sites are taken after the locations of the church in the area, which are $34^{\circ} 49^{\prime} 33.68^{\prime \prime} \mathrm{N}$

that the SEM-EDS analysis of ceramic bodies does not represent the full bulk composition particularly for coarse bodies, but was performed following the standard procedure used in glazed ware examination (Pradell and Molera 2020), complementing the data generated by thin-section petrography, which was our principal method of assessing the ceramic body. The data presented below are an average of five analyses. All measurements were converted to oxides by stoichiometry and normalised to $100 \mathrm{wt} \%$ to account for fluctuations in beam intensity and unavoidable porosity in the analysed areas. Oxides with concentration lower than $0.1 \mathrm{wt} \%$ are not reported as they are below the limits of detection of both instruments.

\section{Results}

\section{Ceramic body}

Petrographic analysis identified three fabric groups, the Amphibole-Serpentine Group, Micaceous Group, and Mixed Carbonate Group. The Amphibole-Serpentine Group $(n=27)$ and $33^{\circ} 24^{\prime} 15.15^{\prime \prime}$ E for the Kofinou Church of Panagia Odigitria, and $35^{\circ} 03^{\prime} 54.55^{\prime \prime} \mathrm{N}$ and $33^{\circ} 26^{\prime} 20.18^{\prime \prime}$ E for Potamia-Agios Sozomenos. Lapithos, Kyrenia and Famagusta are also mentioned in the text, although the exact sites of production in these areas are yet to be found. The coordinates for these sites are based on the location of modern towns: $35^{\circ} 24^{\prime} 55^{\prime \prime} \mathrm{N}$ and $33^{\circ} 36^{\prime} 66^{\prime \prime} \mathrm{E}$ for Lapithos, $35^{\circ} 14^{\prime} 10^{\prime \prime} \mathrm{N}$ and $33^{\circ} 35^{\prime}$ $24^{\prime \prime} \mathrm{E}$ for Kyrenia, $35^{\circ} 10^{\prime} 29^{\prime \prime} \mathrm{N} 35^{\circ} 10^{\prime} 18^{\prime \prime} \mathrm{N}$ and $34^{\circ} 8^{\prime} 22^{\prime \prime} \mathrm{E}$ for Famagusta

has an inclusions:matrix:voids percentage that ranges from around 30:60:10 to 50:45:5. The inclusions consist of around $20-30 \%$ of monocrystalline quartz, $5-15 \%$ of serpentine, amphibole and mudstone fragments, $5-10 \%$ of plagioclase feldspar, pyroxene, biotite and limestone fragments and $<5 \%$ of apatite in a non-calcareous clay matrix (Fig. 4a). The inclusions are well-sorted and homogeneous in grain size (mode size $=0.20 \mathrm{~mm}$ ), with some mudstone and limestone fragments measuring up to $0.80 \mathrm{~mm}$. The Micaceous Group $(n=21)$ stands out for its fine-grained inclusions (mode size $=$ $0.08 \mathrm{~mm}$ ), with its inclusions:matrix:voids percentage ranging from around 20:75:5 to 30:65:5. The inclusions consist of around $10-15 \%$ of biotite and monocrystalline quartz, 5-15\% of limestone fragments, $5 \%$ of iron-rich nodules and $<5 \%$ of quartzite in a calcareous clay matrix (Fig. 4b). The inclusions of the samples in this group are well-sorted. The Mixed Carbonate Group $(n=12)$ has different types of carbonate materials in a micritic clay matrix, with its inclusions:matrix:voids percentage ranging from around 30:60:10 to 50:45:5 (Fig. 4c). The carbonate materials are made up of around 15-20\% of limestone fragments and 
Table 1 The site of recovery, ware type and date of the samples included in this study

\begin{tabular}{|c|c|c|c|c|c|c|c|c|}
\hline Site & $\begin{array}{l}\text { Sample } \\
\text { no. }\end{array}$ & Ware type & Date & $\begin{array}{l}\text { Vessel } \\
\text { form }\end{array}$ & $\begin{array}{l}\text { Interior } \\
\text { slip/paint }\end{array}$ & $\begin{array}{l}\text { Exterior } \\
\text { slip/paint }\end{array}$ & Interior glaze & Exterior glaze \\
\hline \multirow[t]{6}{*}{$\begin{array}{l}\text { Agios Georgios } \\
\text { Hill }\end{array}$} & AG05 & Plain glazed & $\begin{array}{l}\text { 13th to early } 14 \text { th } \\
\text { centuries }\end{array}$ & Bowl & Brown slip & - & Transparent & - \\
\hline & AG06 & White-slipped & $\begin{array}{l}\text { 16th-17th } \\
\text { centuries }\end{array}$ & Bowl & Brown paint & - & Transparent & - \\
\hline & AG10 & Plain glazed & $\begin{array}{l}\text { 13th-early 14th } \\
\text { centuries }\end{array}$ & Bowl & Brown slip & - & Transparent & - \\
\hline & AG18 & Plain glazed & $\begin{array}{l}\text { 13th-early } 14 \text { th } \\
\text { centuries }\end{array}$ & bowl & - & - & Green & - \\
\hline & AG19 & White-slipped & $\begin{array}{l}\text { 16th-17th } \\
\text { centuries }\end{array}$ & Bowl & White slip & White slip & Transparent & Transparent \\
\hline & AG20 & White-slipped & $\begin{array}{l}\text { 16th-17th } \\
\text { centuries }\end{array}$ & Bowl & White slip & White slip & Transparent & Transparent \\
\hline \multirow[t]{8}{*}{ Kofinou } & KF02 & Sgraffito & $\begin{array}{l}\text { 15th-16th } \\
\text { centuries }\end{array}$ & Bowl & White slip & White slip & Yellow & Transparent \\
\hline & KF04 & Sgraffito & $\begin{array}{l}\text { 15th-16th } \\
\text { centuries }\end{array}$ & Bowl & White slip & - & Yellow & Transparent \\
\hline & KF05 & Slip-painted & 13th century & Bowl & White paint & - & Yellow & - \\
\hline & KF06 & White-slipped & 16th century & Bowl & White slip & - & $\begin{array}{l}\text { Transparent, } \\
\text { green }\end{array}$ & - \\
\hline & KF08 & Painted & $\begin{array}{l}\text { 16th-17th } \\
\text { centuries }\end{array}$ & Bowl & Brown paint & - & Brown? & - \\
\hline & KF09 & Painted & $\begin{array}{l}\text { 16th-17th } \\
\text { centuries }\end{array}$ & Bowl & $\begin{array}{l}\text { Green/brown } \\
\text { paint }\end{array}$ & - & Green/brown? & - \\
\hline & KF10 & Plain glazed & 13th century & Bowl & - & - & Green & - \\
\hline & KF13 & Plain glazed & $\begin{array}{l}\text { 16th-17th } \\
\text { centuries }\end{array}$ & Bowl & White slip & White slip & Yellow & Yellow \\
\hline \multirow[t]{20}{*}{ Paphos Theatre } & PT01 & Slip-painted & 13th century & jug & - & $\begin{array}{l}\text { White } \\
\text { paint }\end{array}$ & - & $\begin{array}{l}\text { Transparent/pale } \\
\text { yellow }\end{array}$ \\
\hline & PT02 & Slip-painted & 13th century & Jug & - & $\begin{array}{l}\text { White } \\
\text { paint }\end{array}$ & - & green \\
\hline & PT03 & Slip-painted & 13th century & Jug & - & white paint & - & Yellow \\
\hline & PT04 & Slip-painted & 13th century & Bowl & White paint & - & Green & - \\
\hline & PT05 & Slip-painted & 13th century & Bowl & White paint & - & Yellow & $\begin{array}{r}\text { artially glazed, } \\
\text { transparent? }\end{array}$ \\
\hline & PT06 & Slip-painted & 13th century & Bowl & White paint & - & Transparent? & - \\
\hline & РT07 & Slip-painted & 13th century & Bowl & White paint & $\begin{array}{l}\text { White } \\
\text { paint }\end{array}$ & Yellow & $\begin{array}{l}\text { Transparent/pale } \\
\text { yellow }\end{array}$ \\
\hline & PT08 & Slip-painted & 13th century & Bowl & White paint & - & Yellow & - \\
\hline & РT09 & Plain glazed & 13th century & Bowl & White slip & - & Yellow & - \\
\hline & PT10 & Plain glazed & 13th century & Bowl & White slip & - & Yellow & - \\
\hline & PT11 & Plain glazed & 13th century & Bowl & White slip & - & Green & Transparent? \\
\hline & PT12 & Sgraffito & 13th century & Bowl & White slip & - & $\begin{array}{l}\text { Transparent, } \\
\text { yellow, green }\end{array}$ & Transparent? \\
\hline & PT13 & Sgraffito & 13th century & Bowl & White slip & - & Yellow, green & Transparent? \\
\hline & PT14 & Sgraffito & 13th century & Bowl & White slip & - & $\begin{array}{l}\text { Transparent, } \\
\text { yellow, green }\end{array}$ & Transparent? \\
\hline & PT15 & Sgraffito & 13th century & Bowl & White slip & - & Yellow & Transparent? \\
\hline & PT16 & Sgraffito & 13th century & Bowl & White slip & - & Yellow & Transparent? \\
\hline & PT17 & Sgraffito & 13th century & Bowl & White slip & - & Yellow, green & Transparent? \\
\hline & PT18 & $\begin{array}{l}\text { Sgraffito with } \\
\text { slip-painted } \\
\text { decoration }\end{array}$ & 13th century & Bowl & White slip & $\begin{array}{l}\text { White } \\
\text { paint }\end{array}$ & Green & Green \\
\hline & PT19 & $\begin{array}{c}\text { Sgraffito with } \\
\text { slip-painted } \\
\text { decoration }\end{array}$ & 13 th century & Bowl & White slip & $\begin{array}{l}\text { White } \\
\text { paint }\end{array}$ & Green & Green \\
\hline & PT20 & & 13th century & Bowl & White slip & & Yellow & Yellow \\
\hline
\end{tabular}


Table 1 (continued)

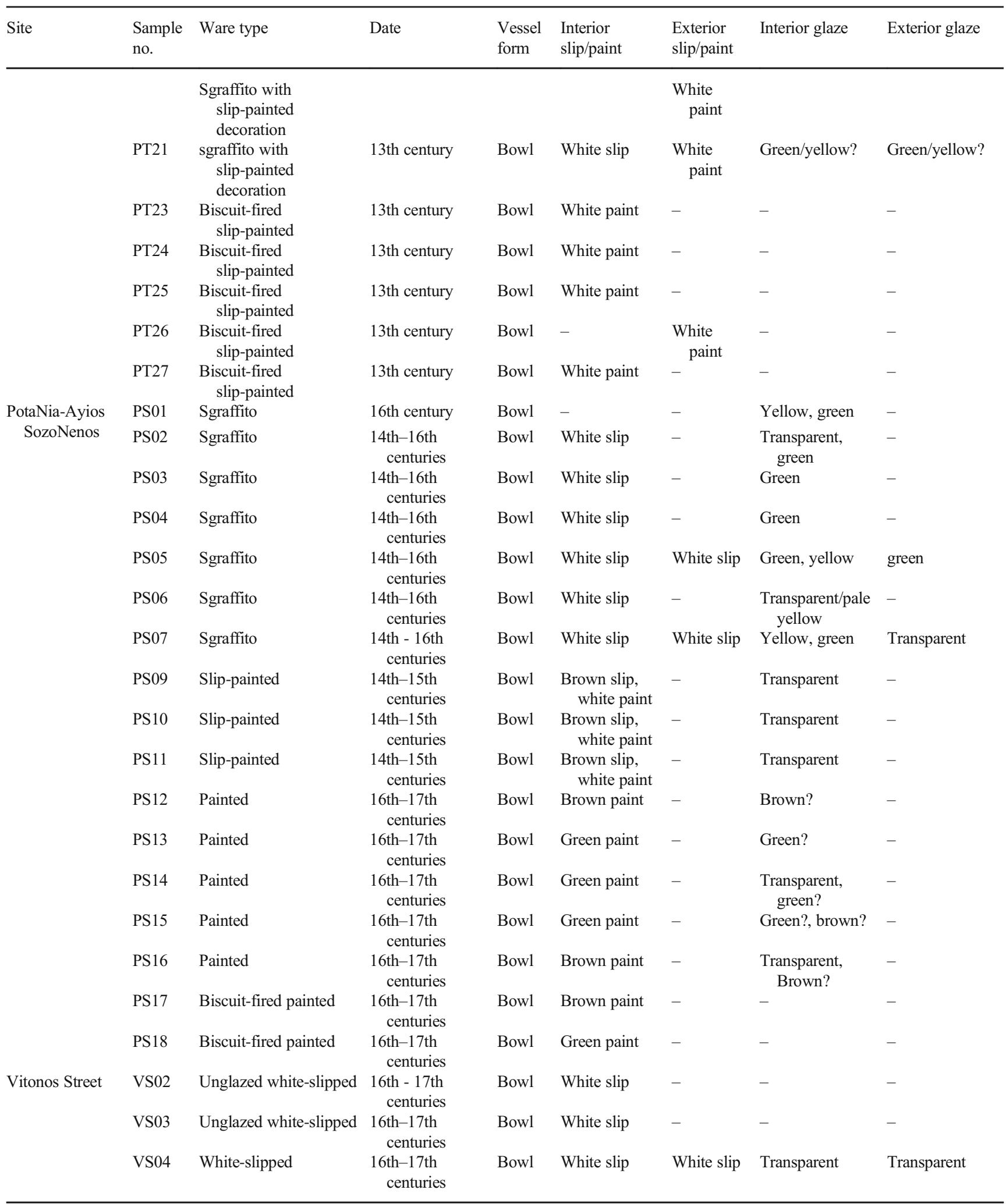




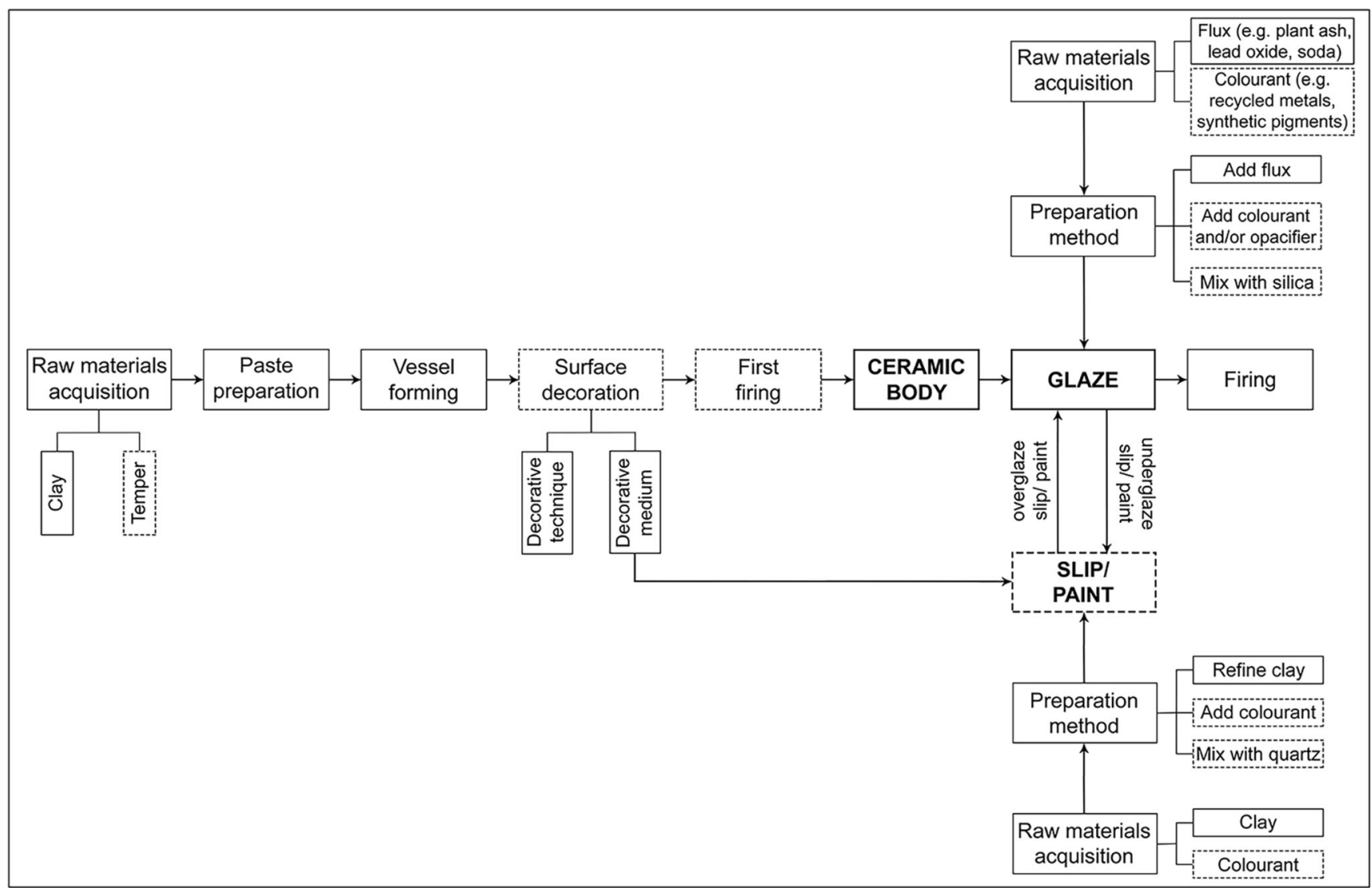

Fig. 3 The chaîne opératoire of glazed ware production. Steps in box with dashed line are optional

calcite, and $10 \%$ of skeletal carbonate grains, which are found together with around $<5$ to $10 \%$ of monocrystalline quartz, and $<5 \%$ of plagioclase feldspar, amphibole and iron-rich nodules. The inclusions are well-sorted and homogeneous in grain size (mode size $=0.20 \mathrm{~mm}$ ), although some quartz and limestone fragments measure up to $0.64 \mathrm{~mm}$. SEM-EDS analysis of the ceramic body confirms the classification of the samples into three compositional groups (Table 2).
Fig. 4 Photomicrographs showing the fabric of a the Amphibole-Serpentine Group (Paphos production), $\mathbf{b}$ the Micaceous Group (Lapithos production) and $\mathbf{c}$ the Mixed Carbonate Group (Famagusta production). All

photomicrographs were taken in cross polarisation at $\times 50$ magnification
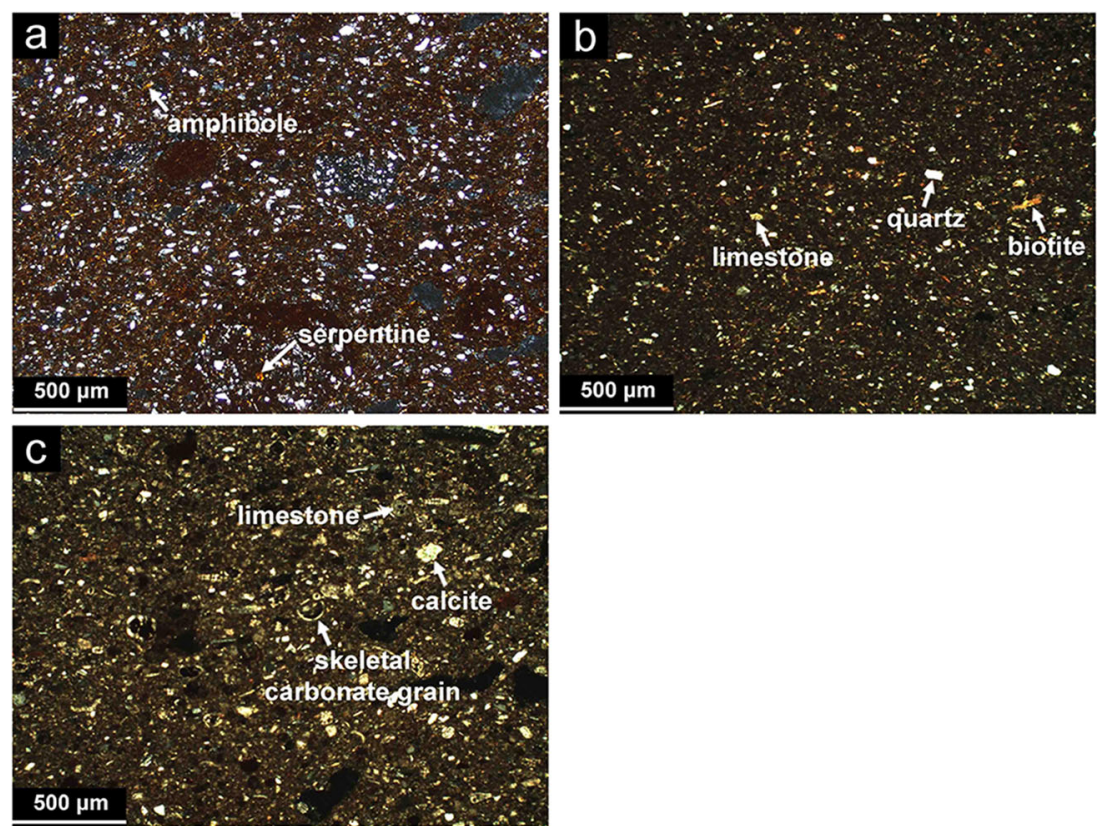
Table 2 The composition (wt\%), mean and standard deviation (st. dev.) of the ceramic body of all samples by SEM-EDS in accordance with the fabric groups. '-' indicates not detected on analysis

\begin{tabular}{|c|c|c|c|c|c|c|c|c|c|c|c|}
\hline Fabric group & Sample no. & $\mathrm{Na}_{2} \mathrm{O}$ & $\mathrm{MgO}$ & $\mathrm{Al}_{2} \mathrm{O}_{3}$ & $\mathrm{SiO}_{2}$ & $\mathrm{P}_{2} \mathrm{O}_{5}$ & $\mathrm{~K}_{2} \mathrm{O}$ & $\mathrm{CaO}$ & $\mathrm{TiO}_{2}$ & $\mathrm{Fe}_{2} \mathrm{O}_{3}$ & $\mathrm{PbO}$ \\
\hline \multirow[t]{29}{*}{ Amphibole-Serpentine $(n=27)$} & KF05 & 0.9 & 2.8 & 14.1 & 65.4 & 0.2 & 3.9 & 4.4 & 1.0 & 7.2 & 0.2 \\
\hline & PT01 & 1.0 & 2.2 & 14.9 & 67.0 & 0.2 & 4.1 & 2.8 & 0.8 & 6.6 & 0.1 \\
\hline & PT02 & 0.7 & 2.2 & 13.7 & 65.1 & 0.3 & 3.7 & 7.3 & 0.6 & 6.1 & 0.4 \\
\hline & PT03 & 0.7 & 2.3 & 14.2 & 62.1 & 0.2 & 3.7 & 9.4 & 0.9 & 6.2 & 0.3 \\
\hline & PT04 & 1.1 & 2.2 & 13.1 & 69.2 & 0.3 & 3.4 & 3.5 & 0.9 & 6.0 & 0.4 \\
\hline & PT05 & 0.8 & 2.4 & 15.3 & 65.3 & 0.3 & 4.0 & 3.8 & 0.7 & 7.1 & 0.2 \\
\hline & РT06 & 1.1 & 2.0 & 13.4 & 66.0 & 0.2 & 3.8 & 6.5 & 0.7 & 6.1 & 0.2 \\
\hline & РT07 & 1.0 & 2.2 & 14.6 & 66.9 & 0.3 & 3.8 & 3.6 & 0.8 & 6.4 & 0.2 \\
\hline & РT08 & 1.0 & 1.8 & 11.3 & 67.2 & 0.3 & 2.8 & 8.7 & 0.6 & 5.7 & 0.4 \\
\hline & РT09 & 1.0 & 2.0 & 13.6 & 67.0 & 0.2 & 3.6 & 4.7 & 0.7 & 6.0 & 1.1 \\
\hline & PT10 & 0.9 & 2.3 & 14.6 & 65.7 & 0.3 & 4.2 & 4.8 & 0.7 & 6.3 & 0.2 \\
\hline & PT11 & 0.9 & 2.2 & 14.6 & 63.2 & 0.3 & 3.4 & 7.2 & 0.7 & 6.7 & 0.7 \\
\hline & PT12 & 0.9 & 2.4 & 14.9 & 64.7 & 0.3 & 4.0 & 5.3 & 0.7 & 6.7 & 0.1 \\
\hline & PT13 & 1.0 & 1.8 & 13.9 & 65.8 & 0.2 & 3.4 & 6.9 & 0.7 & 6.1 & 0.4 \\
\hline & PT14 & 1.0 & 2.0 & 13.6 & 69.4 & 0.2 & 3.3 & 3.5 & 0.8 & 5.9 & 0.2 \\
\hline & PT15 & 0.8 & 2.2 & 15.5 & 64.3 & 0.2 & 3.9 & 4.9 & 1.0 & 7.0 & 0.1 \\
\hline & PT16 & 0.9 & 2.0 & 12.8 & 65.5 & 0.3 & 3.4 & 7.7 & 0.7 & 5.2 & 1.6 \\
\hline & PT17 & 0.9 & 2.1 & 14.4 & 66.1 & 0.2 & 3.6 & 5.1 & 0.7 & 6.3 & 0.6 \\
\hline & PT18 & 0.8 & 2.3 & 14.4 & 64.2 & 0.3 & 3.7 & 6.2 & 0.8 & 6.4 & 1.0 \\
\hline & PT19 & 0.8 & 2.2 & 13.5 & 66.2 & 0.2 & 3.7 & 6.4 & 0.8 & 6.1 & 0.2 \\
\hline & PT20 & 0.8 & 2.2 & 13.3 & 65.2 & 0.2 & 3.3 & 7.2 & 0.7 & 6.3 & 0.7 \\
\hline & PT21 & 0.9 & 2.3 & 14.4 & 65.9 & 0.3 & 3.9 & 4.3 & 0.9 & 7.0 & - \\
\hline & PT23 & 0.8 & 2.2 & 14.0 & 67.7 & - & 3.4 & 5.1 & 0.7 & 5.8 & - \\
\hline & PT24 & 0.7 & 2.5 & 14.5 & 62.7 & 0.1 & 3.6 & 6.7 & 0.9 & 6.8 & 1.2 \\
\hline & PT25 & 0.9 & 2.2 & 13.0 & 66.4 & 0.1 & 3.4 & 6.5 & 0.7 & 5.6 & 0.9 \\
\hline & PT26 & 0.8 & 2.2 & 14.2 & 62.9 & 0.2 & 3.7 & 9.0 & 0.5 & 6.2 & - \\
\hline & РT27 & 0.8 & 2.3 & 13.5 & 66.4 & 0.3 & 3.2 & 6.5 & 0.5 & 6.4 & - \\
\hline & Mean & 0.9 & 2.2 & 14.0 & 65.7 & 0.2 & 3.6 & 5.9 & 0.8 & 6.3 & 0.5 \\
\hline & St. dev. & 0.1 & 0.2 & 0.9 & 1.8 & 0.1 & 0.3 & 1.8 & 0.1 & 0.5 & 0.4 \\
\hline \multirow[t]{17}{*}{ Micaceous $(n=21)$} & AG19 & 1.0 & 4.6 & 15.0 & 49.7 & 0.2 & 2.6 & 16.6 & 0.6 & 7.9 & 2.0 \\
\hline & AG20 & 1.2 & 5.0 & 16.0 & 50.5 & 0.2 & 3.1 & 11.7 & 1.0 & 8.0 & 3.0 \\
\hline & KF02 & 1.1 & 5.0 & 17.3 & 52.8 & 0.2 & 3.4 & 10.9 & 0.8 & 7.9 & 0.6 \\
\hline & KF04 & 1.2 & 4.2 & 16.9 & 54.4 & 0.1 & 3.3 & 12.1 & 0.8 & 6.8 & 0.1 \\
\hline & KF06 & 1.3 & 5.4 & 16.8 & 52.7 & - & 2.8 & 9.9 & 1.1 & 8.9 & 1.0 \\
\hline & KF08 & 1.1 & 6.5 & 16.7 & 50.7 & - & 2.7 & 12.0 & 0.7 & 8.6 & 0.9 \\
\hline & KF09 & 1.2 & 6.4 & 17.7 & 51.5 & - & 3.4 & 9.9 & 0.9 & 8.0 & 1.1 \\
\hline & PS01 & 1.4 & 5.7 & 17.2 & 50.2 & 0.2 & 3.4 & 10.8 & 0.8 & 9.5 & 0.8 \\
\hline & PS02 & 1.1 & 5.9 & 16.3 & 51.7 & 0.2 & 3.2 & 8.8 & 0.9 & 9.4 & 2.6 \\
\hline & PS03 & 1.2 & 5.1 & 17.5 & 51.5 & 0.3 & 3.6 & 11.1 & 1.2 & 8.1 & 0.4 \\
\hline & PS04 & 1.1 & 5.1 & 18.9 & 52.8 & 0.2 & 4.1 & 8.6 & 0.8 & 8.2 & 0.4 \\
\hline & PS06 & 1.0 & 5.3 & 16.6 & 51.4 & 0.2 & 3.0 & 12.4 & 0.8 & 8.3 & 1.0 \\
\hline & PS07 & 0.9 & 5.1 & 15.5 & 50.0 & 0.4 & 2.9 & 15.5 & 0.7 & 7.8 & 1.3 \\
\hline & PS12 & 1.3 & 4.8 & 17.0 & 53.1 & 0.2 & 3.5 & 9.3 & 0.7 & 7.5 & 2.6 \\
\hline & PS13 & 1.1 & 5.7 & 15.4 & 48.6 & 0.2 & 2.8 & 17.4 & 0.7 & 7.6 & 0.4 \\
\hline & PS14 & 1.3 & 5.9 & 18.1 & 50.4 & 0.3 & 3.6 & 9.7 & 0.7 & 8.2 & 1.8 \\
\hline & PS15 & 1.1 & 5.9 & 16.2 & 52.4 & 0.1 & 3.0 & 9.8 & 1.5 & 8.2 & 1.9 \\
\hline
\end{tabular}


Table 2 (continued)

\begin{tabular}{|c|c|c|c|c|c|c|c|c|c|c|c|}
\hline Fabric group & Sample no. & $\mathrm{Na}_{2} \mathrm{O}$ & $\mathrm{MgO}$ & $\mathrm{Al}_{2} \mathrm{O}_{3}$ & $\mathrm{SiO}_{2}$ & $\mathrm{P}_{2} \mathrm{O}_{5}$ & $\mathrm{~K}_{2} \mathrm{O}$ & $\mathrm{CaO}$ & $\mathrm{TiO}_{2}$ & $\mathrm{Fe}_{2} \mathrm{O}_{3}$ & $\mathrm{PbO}$ \\
\hline & PS16 & 1.2 & 5.4 & 17.1 & 52.8 & 0.2 & 3.3 & 9.4 & 0.7 & 8.6 & 1.4 \\
\hline & PS17 & 1.0 & 6.1 & 14.8 & 48.4 & 0.6 & 2.9 & 16.8 & 0.7 & 7.7 & 1.2 \\
\hline & PS18 & 1.1 & 5.6 & 16.6 & 49.5 & 0.3 & 3.4 & 14.4 & 0.8 & 8.3 & 0.1 \\
\hline & VS04 & 1.2 & 5.0 & 16.6 & 52.0 & - & 3.1 & 12.2 & 0.9 & 7.9 & 1.1 \\
\hline & Mean & 1.1 & 5.4 & 16.7 & 51.3 & 0.2 & 3.2 & 11.9 & 0.8 & 8.2 & 1.2 \\
\hline & St. dev. & 0.1 & 0.6 & 1.0 & 1.6 & 0.1 & 0.4 & 2.7 & 0.2 & 0.6 & 0.8 \\
\hline \multirow[t]{14}{*}{ Mixed Carbonate $(n=12)$} & AG05 & 1.1 & 5.8 & 12.7 & 46.5 & 0.5 & 2.2 & 22.6 & 0.7 & 7.1 & 0.5 \\
\hline & AG06 & 1.6 & 4.1 & 12.3 & 45.7 & 0.5 & 1.9 & 23.0 & 0.7 & 7.9 & 2.2 \\
\hline & AG10 & 1.1 & 5.0 & 11.5 & 40.5 & 0.4 & 2.3 & 29.6 & 0.7 & 5.8 & 3.2 \\
\hline & AG18 & 1.6 & 4.4 & 12.9 & 49.9 & - & 1.8 & 18.6 & 0.9 & 8.7 & 1.0 \\
\hline & KF10 & 1.4 & 6.0 & 12.9 & 45.9 & - & 1.5 & 22.4 & 0.9 & 8.2 & 0.8 \\
\hline & KF13 & 1.1 & 5.3 & 12.2 & 46.7 & 0.5 & 1.3 & 23.4 & 0.8 & 8.2 & 0.6 \\
\hline & PS05 & 1.5 & 5.0 & 11.4 & 42.2 & 0.4 & 2.0 & 29.4 & 0.7 & 6.7 & 0.3 \\
\hline & PS09 & 1.7 & 5.2 & 13.8 & 47.4 & 0.2 & 2.4 & 19.5 & 0.9 & 7.8 & 0.9 \\
\hline & PS10 & 1.5 & 4.5 & 11.8 & 43.7 & 0.4 & 2.0 & 27.2 & 0.6 & 7.6 & 0.2 \\
\hline & PS11 & 2.0 & 4.0 & 13.9 & 49.7 & 0.3 & 2.4 & 18.6 & 0.7 & 7.6 & 0.6 \\
\hline & VS02 & 1.6 & 7.1 & 11.7 & 42.2 & - & 1.8 & 26.4 & 0.6 & 7.6 & 0.9 \\
\hline & VS03 & 1.5 & 4.7 & 13.1 & 46.9 & - & 1.8 & 22.7 & 0.8 & 7.8 & 0.6 \\
\hline & Mean & 1.5 & 5.1 & 12.5 & 45.6 & 0.4 & 1.9 & 23.6 & 0.7 & 7.6 & 1.0 \\
\hline & St. dev. & 0.3 & 0.9 & 0.9 & 3.0 & 0.1 & 0.4 & 3.8 & 0.1 & 0.8 & 0.9 \\
\hline
\end{tabular}

The values in italic are the calculation based on the values that are not in italic

\section{Paint and slip}

\section{Microstructure}

The ceramic body of all samples was covered with paint and/or slip. Paint was applied to create specific patterns on the surface of the vessel, whereas slip was used to cover the entire surface. The white paint of the samples of the Amphibole-Serpentine Group, as represented by the slippainted, sgraffito with slip-painted decoration, and biscuitfired slip-painted wares, is thin (ca. 25-65 $\mu \mathrm{m}$ ), with very few to no particles or crystallites (Fig. 5a). The white slip of the monochrome glazed, sgraffito and sgraffito with slip-painted decoration wares of the same fabric group measures between 90 and $205 \mu \mathrm{m}$ in thickness, with around $10 \%$ of quartz particles that are around $20 \mu \mathrm{m}$ in size (see Ting et al. 2019, Fig. 5b).

The brown and green paint of the painted glazed samples of the Micaceous Group has a different microstructure from the paint of the Amphibole-Serpentine Group, as highlighted in their biscuit-fired counterparts (PS17, PS18). Although the paint of both samples is corroded, darker patches and undissolved quartz in a bright matrix can be recognised (Fig. 5b). A paint layer of similar microstructure is not observable in the painted glazed samples that had undergone firing (KF08, KF09, PS12, PS13, PS14, PS15, PS16) (see Fig. 7a). While the white slip of the sgraffito samples of the Micaceous Group is also made of a mixture of quartz and clay, the quartz inclusions display greater heterogeneity in abundance, size and shape (Fig. 6a-c). The quartz particles of PS02, PS03 and PS04 are 10 to $30 \mu \mathrm{m}$ in size, accounting for around $30 \%$ of the slip. The quartz particles of PS06 and PS07 are more angular and coarser-grained (20 to $50 \mu \mathrm{m})$, making up around $80 \%$ of the slip. The quartz particles of KF02 and KF04 are very angular and very coarse-grained (20 to $60 \mu \mathrm{m}$ ), constituting around $50 \%$ of the slip. The slip of the white-slipped samples (AG19, AG20, KF06, VS04) deviates from the slip of the sgraffito belonging to the same fabric group, as it is packed with quartz particles that are homogeneous in size $(20 \mu \mathrm{m})$ and rounder in shape, bound with little clay material (Fig. 6d).

The slip-painted samples of the Mixed Carbonate Group (PS09, PS10, PS11) consists of a layer of white paint made with coarser-grained quartz particles, overlying a brown slip layer with a brighter matrix than the associated ceramic body (Fig. 5c). More variations are observed in the slip of the Mixed Carbonate Group, as evident in the identification of the use of a mixture of quartz particles and clay (AG05, AG10), the presence of fine-grained apatite (PS05) and a compacted layer of non-calcareous clay (KF13). Adding to this variety is the slip of the white-slipped samples of the Mixed Carbonate Group, which displays similar features as those of the Micaceous Group. 
Fig. 5 BSE images showing the different microstructures exhibited by (a) the paint of a biscuit-fired slip-painted sample (PT23) of the AmphiboleSerpentine Group (Paphos production), $\mathbf{b}$ the paint of a biscuit-fired brown-painted sample (PS17) of the Micaceous Group (Lapithos production) and c the presence of an iron-rich slip and paint of the slip-painted sample (PS11) of the Mixed Carbonate Group (Famagusta production)
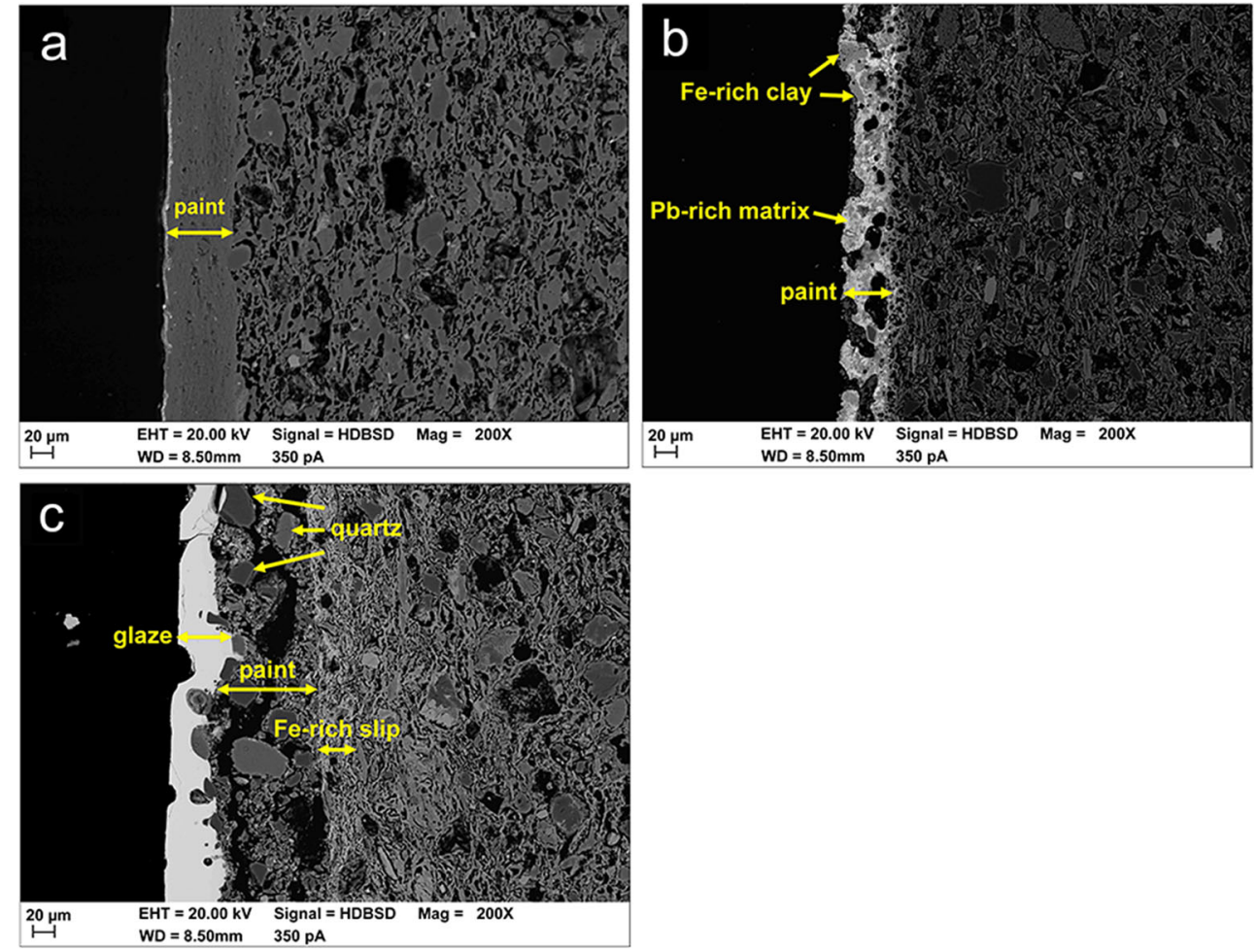

the unglazed biscuit-fired slip-painted samples of the Amphibole-Serpentine Group (PT23, PT24, PT25, PT26, PT27) and the slip of the white-slipped samples of the Mixed Carbonate Group (VS02, VS03) shows that the $\mathrm{PbO}$ concentration is either low or below the limits of detection
With only a few exceptions, the composition of both white paint and slip is consistent with each other and across fabric groups. Noteworthy is that the analysis of the white paint of
Fig. 6 BSE images showing the textural variation of the slip of the sgraffito samples a PS04, b PS06, c KF04 of the Micaceous Group (Lapithos production), and $\mathbf{d}$ the quartz-laden slip specific to the white-slipped sample (VSO3) of the Mixed Carbonate Group (Famagusta production)
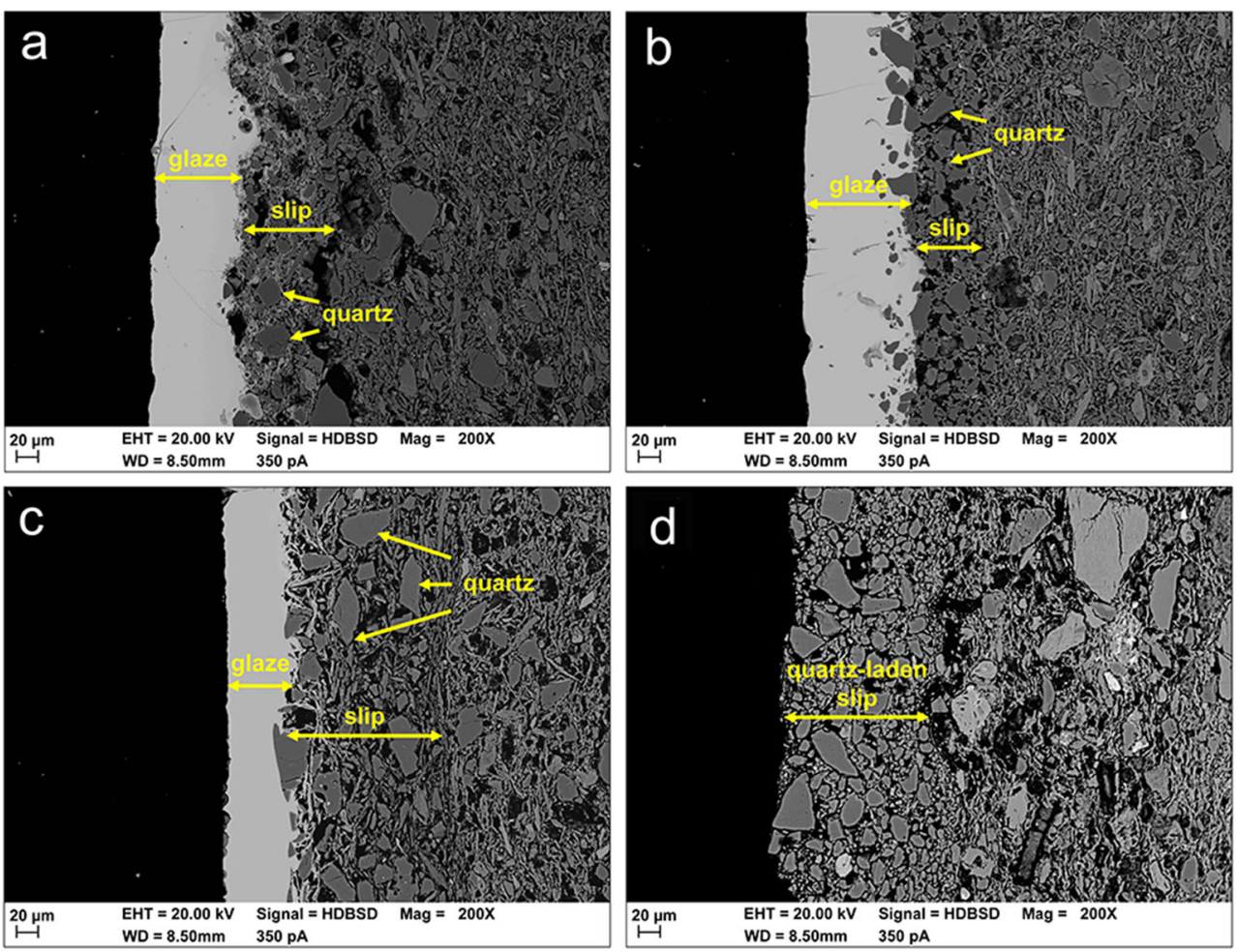
Fig. 7 BSE images showing the presence of a a few

microcrystallites rich in lead and tin oxides in the glaze of sgraffito (PS03) of the Micaceous Group (Lapithos production), b needlelike microcrystallites rich in alumina, silica and lead oxide and equant microcrystallites rich in lime and silica in the glaze of the green-painted sample (PS15) of the Micaceous Group (Lapithos production), $\mathbf{c}$ a thick interaction layer and microcrystallites rich in lead antimonate in the glaze of the plain glazed sample (KF10) of the Mixed Carbonate Group (Famagusta production) and $\mathbf{d}$ microcrystallites rich in lead antimonate in the glaze of the bright, yellow plain glazed sample (KF13) of the Mixed Carbonate Group (Famagusta production)
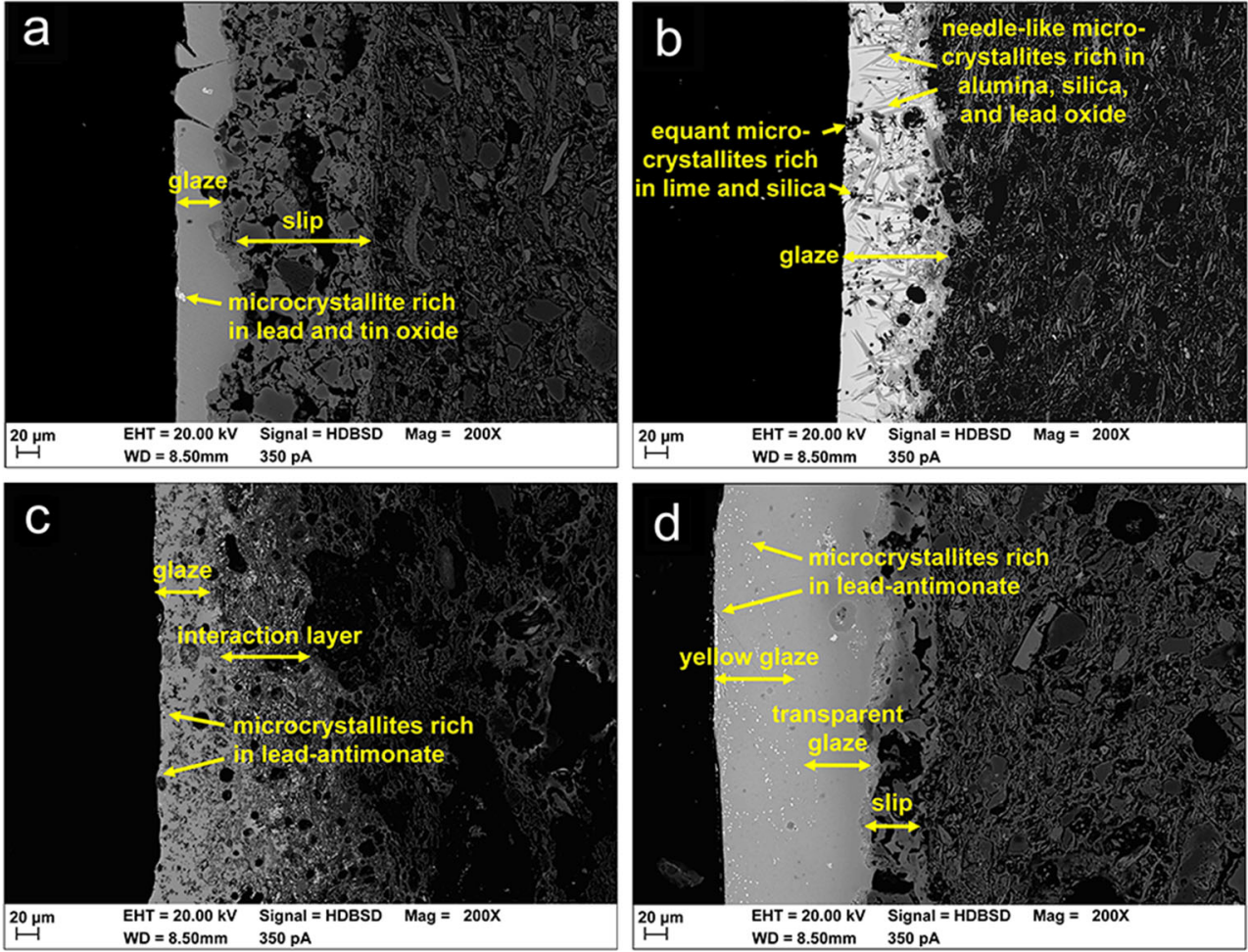

(Table 3). The $\mathrm{PbO}$ concentration in the paint and slip of the glazed ware samples, therefore, likely reflects a reaction with the glaze. Since $\mathrm{PbO}$ is not an original feature of the slips and paints, for the further discussion, it was removed from their composition, which was then renormalised to $100 \mathrm{wt} \%$. Also, the composition of the paint and slip is acquired from analysing both clay and particles as the difference between clay with and without particles is slight and systematic, with higher $\mathrm{SiO}_{2}$ in clay with particles due to added quartz. The paint and slip tend to have higher $\mathrm{Al}_{2} \mathrm{O}_{3}$ and $\mathrm{SiO}_{2}$ and lower $\mathrm{CaO}$ and $\mathrm{Fe}_{2} \mathrm{O}_{3}$ concentration than their associated ceramic body; suggesting that a different, alumina-rich clay was used for the paint/slip and ceramic body.

Although alumina-rich clay was used to make the paint/ slip in most cases, higher $\mathrm{CaO}$ concentration (14.7 to $25.5 \mathrm{wt} \%)$ in the white slip of the sgraffito samples of the Micaceous Group (PS06 and PS07) and the white-slipped sample of the Mixed Carbonate Group (AG06) points to the use of calcareous clays. Higher $\mathrm{Fe}_{2} \mathrm{O}_{3}$ concentration (8.5 to $9.6 \mathrm{wt} \%$ ) in the brown slip of the slip-painted samples of the Micaceous Group (PS09, PS10, PS11) and the plain glazed (AG05, AG10) of the Mixed Carbonate Group suggests that an iron-rich clay was used or iron oxide was added to the clay to enhance the colour. Other exceptions are the brown and green paint of the painted glazed samples of the Micaceous Group. Analysis of the unglazed biscuit-fired painted-glazed samples (PS17, PS18) reveals that the darker patches of the paint are non-calcareous clay with enriched $\mathrm{Fe}_{2} \mathrm{O}_{3}$ or $\mathrm{CuO}$ concentration, whereas the brighter matrix has high $\mathrm{PbO}$ concentration (ca. $29 \mathrm{wt} \%$ ). The addition of lead oxide to the slip or paint is likely to have strengthened the bond between the glaze and ceramic body, especially when double firing was performed (Molera et al. 2020).

\section{Glaze}

\section{Microstructure}

The thickness of the glaze varies across ware types and fabric groups (Table 4). All samples of the Amphibole-Serpentine Group have a thin interaction layer between the painted or slipped ceramic body and glaze, with a few bright microparticles being found to have scattered in the glaze of some samples (PT04, PT11, PT14 and PT21) (see Ting et al. 2019, Fig. 5c). A similar microstructure can be observed in the glaze of most samples of the Micaceous and Mixed Carbonate Groups (Fig. 7a), but with a few exceptions. The painted glazed samples of the Micaceous Group (KF08, KF09, PS12, PS13, PS14, PS15, PS16) have needle-like and dark, equant microcrystallites, especially in the areas where the brown and green paint was applied (Fig. 7b). The glaze of the plain glazed samples of the Mixed Carbonate Group (AG18, KF10) is characterised by dark, elongated and equant microcrystallites throughout (Fig. 7c). The glaze of KF10 has bright microparticles $(<10 \mu \mathrm{m})$ concentrated at the glaze margin. These bright microparticles are also identified along the glaze margin of another plain glazed sample of the same 
Table 3 The composition (wt\%), mean, and standard deviation (st. dev.) of the paint (P) and slip (SL) of the samples by SEM-EDS. I interior surface, $E$ exterior surface. '-' indicates not detected on analysis

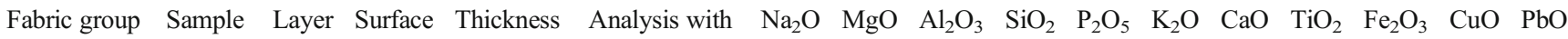
no. (um) inclusions

\begin{tabular}{|c|c|c|c|c|c|c|c|c|c|c|c|c|c|c|c|c|}
\hline \multirow{45}{*}{$\begin{array}{l}\text { Amphibole- } \\
\text { Serpentine }\end{array}$} & KF05 & $\mathrm{P}$ & I & 65 & $\mathrm{~N}$ & 0.9 & 3.3 & 19.0 & 55.5 & - & 4.6 & 1.4 & 0.4 & 6.8 & - & 8.0 \\
\hline & PT01 & $\mathrm{P}$ & E & 60 & $\mathrm{~N}$ & 0.7 & 1.3 & 12.9 & 51.9 & 0.3 & 3.2 & 1.9 & 1.0 & 3.7 & - & 23.1 \\
\hline & PT02 & $\mathrm{P}$ & $\mathrm{E}$ & 50 & $\mathrm{~N}$ & 0.9 & 0.9 & 20.7 & 53.7 & 0.2 & 4.4 & 0.9 & 1.4 & 2.6 & - & 14.1 \\
\hline & PT03 & $\mathrm{P}$ & E & 55 & $\mathrm{~N}$ & 0.8 & 2.3 & 15.7 & 58.2 & 0.1 & 4.6 & 3.9 & 0.6 & 6.2 & - & 7.7 \\
\hline & РT04 & $\mathrm{P}$ & I & 60 & $\mathrm{~N}$ & 0.5 & 0.4 & 16.7 & 58.8 & 0.1 & 2.9 & 0.4 & 1.1 & 1.7 & - & 17.2 \\
\hline & PT05 & $\mathrm{P}$ & I & 40 & $\mathrm{~N}$ & 1.0 & 0.8 & 20.7 & 50.7 & - & 4.5 & 2.6 & 0.7 & 2.5 & - & 16.3 \\
\hline & PT06 & $\mathrm{P}$ & I & 65 & $\mathrm{~N}$ & 1.0 & 1.9 & 19.8 & 47.7 & 0.2 & 4.5 & 2.1 & 0.8 & 5.8 & - & 16.3 \\
\hline & PT07 & $\mathrm{P}$ & I & 55 & $\mathrm{~N}$ & 0.8 & 2.0 & 14.9 & 53.0 & 0.2 & 3.8 & 2.1 & 0.8 & 5.4 & - & 17.1 \\
\hline & & & $\mathrm{E}$ & 55 & $\mathrm{~N}$ & 0.7 & 1.5 & 14.0 & 56.9 & 0.1 & 3.3 & 0.9 & 1.4 & 6.8 & - & 14.4 \\
\hline & РT08 & $\mathrm{P}$ & I & 40 & $\mathrm{~N}$ & 1.5 & 0.9 & 24.3 & 52.3 & - & 4.7 & 1.7 & 0.8 & 2.7 & - & 11.1 \\
\hline & РT09 & SL & I & 90 & $\mathrm{Y}$ & 0.8 & 0.6 & 21.3 & 42.0 & 0.4 & 3.4 & 0.6 & 1.3 & 3.4 & - & 26.3 \\
\hline & PT10 & SL & I & 80 & $\mathrm{~N}$ & 0.6 & 0.6 & 22.2 & 52.8 & - & 4.6 & 0.6 & 0.4 & 1.7 & - & 16.4 \\
\hline & & & & & $\mathrm{Y}$ & 0.6 & 1.0 & 19.6 & 55.7 & 0.1 & 3.8 & 2.8 & 0.8 & 3.2 & - & 12.1 \\
\hline & PT11 & SL & I & 115 & $\mathrm{~N}$ & 0.8 & 0.6 & 27.8 & 41.2 & - & 4.1 & 0.5 & 1.8 & 1.4 & - & 21.5 \\
\hline & & & & & $\mathrm{Y}$ & 0.7 & 0.6 & 21.7 & 52.3 & 0.1 & 4.1 & 0.6 & 0.9 & 1.4 & - & 17.3 \\
\hline & PT12 & SL & I & 100 & $\mathrm{~N}$ & 0.9 & 1.0 & 23.2 & 42.3 & 0.1 & 4.6 & 1.1 & 1.4 & 2.7 & - & 22.8 \\
\hline & & & & & $\mathrm{Y}$ & 0.9 & 2.5 & 15.4 & 59.7 & 0.2 & 4.1 & 3.3 & 0.8 & 6.4 & - & 6.7 \\
\hline & PT13 & SL & I & 90 & $\mathrm{~N}$ & 0.8 & 0.3 & 26.8 & 48.0 & - & 3.9 & 0.2 & 0.6 & 1.3 & - & 17.7 \\
\hline & & & & & $\mathrm{Y}$ & 1.0 & 0.6 & 27.9 & 47.0 & - & 4.7 & 0.3 & 0.7 & 1.6 & - & 16.2 \\
\hline & PT14 & $\mathrm{SL}$ & I & 100 & $\mathrm{~N}$ & 0.6 & 0.6 & 21.8 & 44.9 & - & 3.8 & 0.6 & 1.7 & 1.8 & - & 24.1 \\
\hline & & & & & $\mathrm{Y}$ & 0.5 & 0.5 & 20.6 & 48.4 & - & 3.8 & 0.4 & 1.7 & 1.1 & - & 22.5 \\
\hline & PT15 & SL & I & 95 & $\mathrm{~N}$ & 0.6 & 0.6 & 24.4 & 49.1 & 0.4 & 4.7 & 1.0 & 2.0 & 2.6 & - & 14.6 \\
\hline & & & & & $\mathrm{Y}$ & 0.6 & 0.4 & 19.3 & 57.6 & - & 3.5 & 0.3 & 1.5 & 1.4 & - & 14.7 \\
\hline & PT16 & SL & I & 205 & $\mathrm{~N}$ & 0.8 & 0.4 & 29.1 & 41.8 & 0.1 & 4.5 & 0.5 & 1.5 & 1.4 & - & 19.8 \\
\hline & & & & & $\mathrm{Y}$ & 0.6 & 0.4 & 15.6 & 60.7 & 0.5 & 2.8 & 2.4 & 0.9 & 1.2 & - & 14.8 \\
\hline & PT17 & SL & I & 195 & $\mathrm{~N}$ & 0.6 & 0.7 & 24.6 & 36.2 & - & 3.9 & 0.4 & 1.0 & 1.8 & - & 30.7 \\
\hline & & & & & $\mathrm{Y}$ & 0.5 & 0.4 & 17.5 & 52.8 & 0.1 & 3.0 & 0.3 & 0.9 & 1.0 & - & 23.5 \\
\hline & PT18 & SL & I & 140 & $\mathrm{~N}$ & 0.8 & 0.5 & 29.0 & 44.0 & - & 4.5 & 0.4 & 0.9 & 1.6 & - & 18.0 \\
\hline & & & & & $\mathrm{Y}$ & 0.5 & 0.4 & 14.5 & 66.3 & - & 2.8 & 0.4 & 1.0 & 1.0 & - & 13.0 \\
\hline & & $\mathrm{P}$ & $\mathrm{E}$ & 80 & $\mathrm{~N}$ & 0.9 & 0.4 & 29.0 & 50.4 & 0.1 & 3.9 & 0.5 & 0.9 & 1.5 & - & 12.2 \\
\hline & & & & & $\mathrm{Y}$ & 0.6 & 0.4 & 17.0 & 67.0 & 0.2 & 3.0 & 0.6 & 0.8 & 1.3 & - & 8.9 \\
\hline & PT19 & SL & I & 105 & $\mathrm{~N}$ & 0.7 & 0.8 & 29.6 & 41.5 & - & 3.7 & 0.3 & 1.0 & 1.6 & - & 20.7 \\
\hline & & & & & $\mathrm{Y}$ & 0.7 & 0.6 & 20.8 & 50.9 & - & 3.5 & 1.5 & 1.9 & 1.7 & - & 18.4 \\
\hline & & $\mathrm{P}$ & $\mathrm{E}$ & 90 & $\mathrm{~N}$ & 0.7 & 0.4 & 23.0 & 43.7 & - & 4.1 & 0.7 & 0.9 & 1.3 & - & 24.8 \\
\hline & & & & & $\mathrm{Y}$ & 1.1 & 3.3 & 19.6 & 54.0 & - & 4.9 & 2.5 & 0.4 & 6.3 & - & 7.9 \\
\hline & РT20 & SL & I & 100 & $\mathrm{~N}$ & 0.8 & 0.6 & 29.9 & 44.5 & - & 4.5 & 0.5 & 0.3 & 1.3 & - & 17.5 \\
\hline & & & & & $\mathrm{Y}$ & 0.7 & 0.4 & 19.2 & 54.9 & - & 3.6 & 0.5 & 2.0 & 1.5 & - & 17.0 \\
\hline & & $\mathrm{P}$ & $\mathrm{E}$ & 55 & $\mathrm{~N}$ & 0.7 & 0.5 & 24.1 & 37.5 & 0.4 & 3.5 & 0.6 & 1.3 & 2.1 & - & 29.2 \\
\hline & & & & & $\mathrm{Y}$ & 0.9 & 0.7 & 20.3 & 43.2 & 4.0 & 4.3 & 0.6 & 0.7 & 1.8 & - & 23.5 \\
\hline & PT21 & SL & I & 90 & $\mathrm{~N}$ & 0.7 & 0.7 & 21.0 & 43.9 & 0.8 & 4.2 & 2.8 & 0.9 & 1.8 & - & 23.1 \\
\hline & & & & & $\mathrm{Y}$ & 0.8 & 3.0 & 16.3 & 50.4 & 0.1 & 4.7 & 2.7 & 0.8 & 8.4 & - & 12.8 \\
\hline & & $\mathrm{P}$ & E & 120 & $\mathrm{~N}$ & 0.7 & 2.6 & 15.1 & 52.4 & - & 4.6 & 2.2 & 0.4 & 8.6 & - & 13.4 \\
\hline & & & & & $\mathrm{Y}$ & 0.8 & 2.4 & 14.9 & 56.9 & 0.2 & 3.9 & 3.7 & 0.6 & 6.9 & - & 9.7 \\
\hline & РT23 & $\mathrm{P}$ & I & 60 & $\mathrm{~N}$ & 1.0 & 0.8 & 35.2 & 53.7 & - & 4.7 & 0.3 & 1.2 & 2.5 & - & 0.6 \\
\hline & $\mathrm{PT} 24$ & $\mathrm{P}$ & I & 50 & $\mathrm{~N}$ & 1.8 & 1.1 & 35.8 & 50.5 & - & 5.5 & 0.9 & 0.8 & 2.9 & - & 0.6 \\
\hline \multirow[t]{23}{*}{ Micaceous } & PT25 & $\mathrm{P}$ & I & 50 & $\mathrm{~N}$ & 1.2 & 0.8 & 33.4 & 53.9 & - & 6.1 & 0.6 & 1.0 & 2.4 & - & 0.6 \\
\hline & PT26 & $\mathrm{P}$ & $\mathrm{E}$ & 30 & $\mathrm{~N}$ & 2.6 & 0.9 & 33.4 & 46.3 & - & 9.4 & 1.6 & 0.6 & 2.6 & - & 2.5 \\
\hline & PT27 & $\mathrm{P}$ & I & 25 & $\mathrm{~N}$ & 0.9 & 1.2 & 34.8 & 50.8 & 0.2 & 5.5 & 0.8 & 0.9 & 2.5 & - & 0.6 \\
\hline & & & & & Mean (paint) & 1.0 & 1.4 & 22.0 & 52.6 & 0.5 & 4.5 & 1.5 & 0.9 & 3.9 & - & 12.0 \\
\hline & & & & & St. dev. (paint) & 0.4 & 0.9 & 7.6 & 6.4 & 1.1 & 1.3 & 1.0 & 0.3 & 2.2 & - & 8.1 \\
\hline & & & & & Mean (slip) & 0.7 & 0.7 & 22.4 & 49.2 & 0.3 & 4.0 & 1.0 & 1.1 & 2.2 & - & 18.5 \\
\hline & & & & & St. dev. (slip) & 0.1 & 0.6 & 4.8 & 7.3 & 0.2 & 0.6 & 1.0 & 0.5 & 1.7 & - & 5.2 \\
\hline & AG19 & SL & I & 135 & $\mathrm{~N}$ & 3.8 & 1.3 & 18.6 & 62.4 & 0.2 & 7.5 & 1.6 & 1.2 & 0.6 & - & 2.8 \\
\hline & & & & & $\mathrm{Y}$ & 0.6 & 0.6 & 7.8 & 81.1 & 0.2 & 5.9 & 1.1 & 0.5 & 0.5 & - & 1.7 \\
\hline & & & $\mathrm{E}$ & 145 & $\mathrm{~N}$ & 2.5 & 1.1 & 18.1 & 62.4 & 0.1 & 10.5 & 1.5 & 1.5 & 0.5 & - & 1.9 \\
\hline & & & & & $\mathrm{Y}$ & 0.6 & 0.7 & 8.9 & 74.1 & - & 7.1 & 5.9 & 0.1 & 0.4 & - & 2.3 \\
\hline & AG20 & SL & I & 100 & $\mathrm{~N}$ & 1.0 & 1.7 & 22.7 & 46.1 & - & 4.9 & 0.7 & 0.1 & 1.0 & - & 21.7 \\
\hline & & & & & $\mathrm{Y}$ & 1.4 & 1.2 & 15.3 & 60.6 & - & 4.8 & 1.0 & 0.2 & 1.5 & - & 14.0 \\
\hline & & & $\mathrm{E}$ & 115 & $\mathrm{~N}$ & 1.3 & 1.9 & 22.6 & 56.7 & - & 5.9 & 0.9 & - & 1.4 & - & 9.3 \\
\hline & & & & & $\mathrm{Y}$ & 1.5 & 1.1 & 14.8 & 67.4 & - & 4.9 & 1.2 & 0.3 & 1.4 & - & 7.3 \\
\hline & KF02 & SL & I & 170 & $\mathrm{~N}$ & 1.0 & 1.1 & 28.5 & 45.4 & - & 5.0 & 0.4 & 0.3 & 1.2 & - & 17.1 \\
\hline & & & & & $\mathrm{Y}$ & 0.4 & 0.3 & 7.7 & 81.7 & - & 2.5 & 0.3 & 0.4 & 0.6 & - & 6.3 \\
\hline & & & E & 155 & $\mathrm{~N}$ & 0.9 & 1.1 & 27.1 & 47.5 & - & 4.5 & 0.2 & 0.5 & 1.9 & - & 16.1 \\
\hline & & & & & $\mathrm{Y}$ & 0.3 & 0.4 & 8.6 & 79.0 & - & 2.5 & 0.2 & 0.5 & 1.0 & - & 7.5 \\
\hline & KF04 & SL & I & 140 & $\mathrm{~N}$ & 0.9 & 0.7 & 32.8 & 51.2 & - & 4.8 & 0.7 & 0.5 & 1.7 & - & 6.7 \\
\hline & & & & & $\mathrm{Y}$ & 0.4 & 0.9 & 15.7 & 75.4 & - & 2.3 & 2.0 & 0.8 & 0.9 & - & 1.6 \\
\hline & KF06 & $\mathrm{SL}$ & I & 45 & $\mathrm{~N}$ & 2.0 & 2.1 & 13.5 & 65.5 & - & 5.6 & 0.8 & 0.1 & 1.6 & - & 8.8 \\
\hline & & & & & $\mathrm{Y}$ & 1.8 & 3.8 & 13.7 & 58.4 & - & 4.9 & 1.2 & 0.1 & 2.3 & - & 13.7 \\
\hline
\end{tabular}


Table 3 (continued)

\begin{tabular}{|c|c|c|c|c|c|c|c|c|c|c|c|c|c|c|c|c|}
\hline Fabric group & $\begin{array}{l}\text { Sample } \\
\text { no. }\end{array}$ & Layer & Surface & $\begin{array}{l}\text { Thickness } \\
\text { (um) }\end{array}$ & $\begin{array}{l}\text { Analysis with } \\
\text { inclusions }\end{array}$ & $\mathrm{Na}_{2} \mathrm{O}$ & $\mathrm{MgO}$ & $\mathrm{Al}_{2} \mathrm{O}_{3}$ & $\mathrm{SiO}_{2}$ & $\mathrm{P}_{2} \mathrm{O}_{5}$ & $\mathrm{~K}_{2} \mathrm{O}$ & $\mathrm{CaO}$ & $\mathrm{TiO}_{2}$ & $\mathrm{Fe}_{2} \mathrm{O}_{3}$ & $\mathrm{CuO}$ & $\mathrm{PbO}$ \\
\hline & PS02 & SL & I & 100 & $\mathrm{~N}$ & 2.2 & 0.9 & 13.6 & 62.3 & - & 5.2 & 2.0 & 0.1 & 1.5 & - & 12.1 \\
\hline & & & & & $\mathrm{Y}$ & 1.8 & 0.9 & 12.6 & 59.3 & - & 4.4 & 6.6 & 0.3 & 2.5 & - & 11.5 \\
\hline & PS03 & SL & I & 135 & $\mathrm{~N}$ & 1.4 & 1.4 & 24.9 & 40.4 & 0.1 & 4.1 & 0.8 & 0.1 & 0.9 & - & 25.8 \\
\hline & & & & & $\mathrm{Y}$ & 1.5 & 1.0 & 15.3 & 60.6 & - & 5.3 & 3.0 & 0.2 & 1.2 & - & 11.7 \\
\hline & PS04 & SL & I & 80 & $\mathrm{~N}$ & 0.6 & 1.9 & 20.3 & 54.8 & - & 4.6 & 2.6 & 1.6 & 1.8 & - & 11.7 \\
\hline & & & & & $\mathrm{Y}$ & 0.4 & 1.6 & 12.5 & 69.0 & - & 3.4 & 2.6 & 0.1 & 1.5 & - & 8.7 \\
\hline & PS06 & SL & I & 75 & $\mathrm{~N}$ & 0.5 & 0.7 & 5.6 & 59.8 & - & 3.0 & 25.5 & 0.1 & 0.6 & - & 4.2 \\
\hline & & & & & $\mathrm{Y}$ & 0.3 & 0.3 & 4.0 & 88.4 & - & 2.1 & 2.1 & 0.1 & 0.6 & - & 2.1 \\
\hline & PS07 & SL & I & 75 & $\mathrm{~N}$ & 0.5 & 0.7 & 6.6 & 69.2 & - & 2.7 & 14.7 & 0.3 & 0.8 & - & 4.2 \\
\hline & & & & & $\mathrm{Y}$ & 0.6 & 0.4 & 7.2 & 76.6 & 0.1 & 3.0 & 5.3 & 0.4 & 0.9 & - & 5.5 \\
\hline & & & E & & $\mathrm{N}$ & 0.3 & 1.2 & 5.5 & 70.0 & 0.1 & 2.0 & 16.3 & 0.2 & 0.7 & - & 3.6 \\
\hline & & & & & $\mathrm{Y}$ & 0.5 & 0.4 & 6.8 & 78.7 & - & 2.7 & 4.5 & 0.6 & 0.8 & - & 4.9 \\
\hline & PS17 & $\mathrm{P}$ & I & 50 & $\mathrm{Y}$ & 0.3 & 2.0 & 4.3 & 20.5 & - & 0.4 & 4.2 & 0.1 & 39.0 & - & 29.0 \\
\hline & PS18 & $\mathrm{P}$ & I & 50 & $\mathrm{Y}$ & 0.8 & 0.7 & 7.4 & 38.5 & - & 1.5 & 0.6 & 0.1 & 1.0 & 2.2 & 47.3 \\
\hline & VS04 & SL & I & 135 & $\mathrm{~N}$ & 0.6 & 0.7 & 13.8 & 65.2 & - & 3.8 & 0.3 & 0.3 & 0.7 & - & 14.6 \\
\hline & & & & & $\mathrm{Y}$ & 0.3 & 0.3 & 6.7 & 83.1 & - & 2.2 & 0.2 & 0.3 & 0.5 & - & 6.5 \\
\hline & & & E & 85 & $\mathrm{~N}$ & 0.7 & 1.2 & 21.4 & 51.2 & - & 5.6 & 0.4 & 0.6 & 1.2 & - & 17.7 \\
\hline & & & & & $\mathrm{Y}$ & 0.3 & 0.3 & 7.4 & 80.5 & - & 2.5 & 0.3 & 0.3 & 0.5 & - & 7.9 \\
\hline & & & & & Mean (paint) & 0.6 & 1.4 & 5.9 & 29.5 & - & 0.9 & 2.4 & 0.1 & 20.0 & 2.2 & 38.1 \\
\hline & & & & & St. dev. (paint) & 0.4 & 1.0 & 2.2 & 12.7 & - & 0.8 & 2.6 & 0.03 & 26.9 & - & 12.9 \\
\hline & & & & & Mean (slip) & 1.0 & 1.0 & 14.4 & 65.1 & 0.2 & 4.3 & 3.4 & 0.4 & 1.1 & - & 9.1 \\
\hline & & & & & St. dev. (slip) & 0.8 & 0.7 & 7.7 & 12.6 & 0.03 & 1.9 & 5.6 & 0.4 & 0.6 & - & 6.2 \\
\hline \multirow{28}{*}{$\begin{array}{l}\text { Mixed } \\
\quad \text { Carbonate }\end{array}$} & AG05 & SL & I & 140 & $\mathrm{~N}$ & 0.6 & 2.2 & 23.3 & 38.7 & 2.0 & 4.5 & 3.4 & 2.2 & 6.3 & - & 16.9 \\
\hline & & & & & $\mathrm{Y}$ & 0.8 & 2.9 & 20.2 & 37.4 & 1.9 & 4.7 & 1.8 & 1.0 & 7.5 & - & 21.9 \\
\hline & AG06 & $\mathrm{P}$ & I & 50 & $\mathrm{~N}$ & 1.2 & 6.1 & 12.3 & 41.3 & 1.8 & 1.4 & 13.1 & 2.8 & 8.8 & - & 11.2 \\
\hline & AG10 & SL & I & 50 & $\mathrm{~N}$ & 0.8 & 2.4 & 20.5 & 36.2 & 1.4 & 4.8 & 1.6 & 1.4 & 6.4 & - & 24.4 \\
\hline & & & & & Y & 0.7 & 2.8 & 20.4 & 40.0 & 1.3 & 4.5 & 2.4 & 0.5 & 6.1 & - & 20.8 \\
\hline & KF13 & SL & I & 50 & $\mathrm{~N}$ & 2.3 & 4.5 & 17.6 & 59.3 & - & 6.3 & 1.4 & 0.1 & 2.4 & - & 6.1 \\
\hline & & & E & 60 & $\mathrm{~N}$ & 2.3 & 4.7 & 16.9 & 55.2 & - & 6.5 & 1.5 & 0.1 & 2.3 & - & 10.3 \\
\hline & PS05 & SL & I & 70 & $\mathrm{~N}$ & 0.5 & 2.1 & 32.9 & 54.4 & - & 7.3 & 1.6 & 0.1 & 0.9 & - & 0.2 \\
\hline & & & & & $\mathrm{Y}$ & 0.4 & 1.4 & 25.2 & 63.3 & 0.4 & 5.4 & 2.4 & 0.2 & 1.1 & - & 0.2 \\
\hline & & & E & 55 & $\mathrm{~N}$ & 0.3 & 2.1 & 31.7 & 54.9 & 0.7 & 7.0 & 2.0 & 0.1 & 0.8 & - & 0.3 \\
\hline & & & & & Y & 0.3 & 1.7 & 25.4 & 64.2 & - & 5.9 & 1.4 & 0.3 & 0.7 & - & 0.2 \\
\hline & PS09 & SL & I & 30 & $\mathrm{Y}$ & 1.0 & 6.4 & 27.5 & 46.1 & 0.2 & 6.2 & 0.9 & 1.2 & 9.5 & - & 0.9 \\
\hline & & $\mathrm{P}$ & & 100 & $\mathrm{~N}$ & 0.8 & 0.9 & 13.7 & 68.5 & - & 8.7 & 0.5 & 0.2 & 0.4 & - & 6.2 \\
\hline & & & & & Y & 0.5 & 1.1 & 9.7 & 75.1 & 0.3 & 6.4 & 1.2 & 0.6 & 1.1 & - & 4.2 \\
\hline & PS10 & SL & I & 115 & $\mathrm{Y}$ & 1.4 & 6.4 & 22.9 & 49.2 & 0.2 & 4.9 & 4.3 & 1.1 & 9.2 & - & 0.4 \\
\hline & & $\mathrm{P}$ & & 110 & $\mathrm{~N}$ & 0.5 & 1.4 & 10.5 & 74.0 & 0.1 & 6.9 & 1.3 & 0.9 & 1.0 & - & 3.5 \\
\hline & & & & & $\mathrm{Y}$ & 0.7 & 1.0 & 10.3 & 73.3 & 0.2 & 5.2 & 0.6 & 0.1 & 0.5 & - & 8.1 \\
\hline & PS11 & SL & I & 140 & $\mathrm{Y}$ & 1.1 & 8.2 & 16.6 & 50.8 & 0.3 & 5.8 & 5.9 & 1.5 & 9.2 & - & 0.6 \\
\hline & & $\mathrm{P}$ & & 165 & $\mathrm{~N}$ & 0.9 & 0.7 & 20.2 & 66.3 & 0.2 & 4.1 & 0.5 & 0.5 & 0.9 & - & 5.7 \\
\hline & & & & & $\mathrm{Y}$ & 0.7 & 0.4 & 18.9 & 69.8 & 0.3 & 3.8 & 0.5 & 1.1 & 1.0 & - & 3.5 \\
\hline & VS02 & SL & I & 165 & $\mathrm{~N}$ & 3.0 & 4.4 & 16.1 & 58.0 & - & 5.7 & 5.7 & 0.2 & 4.7 & - & 2.1 \\
\hline & & & & & $\mathrm{Y}$ & 0.4 & 1.2 & 5.2 & 83.2 & - & 2.9 & 2.4 & 0.2 & 2.0 & - & 2.5 \\
\hline & VS03 & SL & I & 75 & $\mathrm{~N}$ & 1.2 & 1.4 & 19.9 & 61.2 & - & 5.8 & 0.4 & 0.5 & 0.9 & - & 8.8 \\
\hline & & & & & Y & 0.3 & 0.4 & 5.2 & 87.6 & - & 1.9 & 0.4 & 1.1 & 0.5 & - & 2.4 \\
\hline & & & & & Mean (paint) & 0.7 & 0.9 & 13.9 & 71.2 & 0.2 & 5.8 & 0.8 & 0.6 & 0.8 & - & 5.2 \\
\hline & & & & & St. dev. (paint) & 0.2 & 0.3 & 4.6 & 3.5 & 0.1 & 1.9 & 0.4 & 0.4 & 0.3 & - & 1.8 \\
\hline & & & & & Mean (slip) & 1.2 & 3.8 & 18.5 & 55.9 & 0.9 & 5.0 & 3.1 & 0.8 & 4.7 & - & 6.6 \\
\hline & & & & & St. dev. (slip) & 0.8 & 2.4 & 7.7 & 15.1 & 0.8 & 1.8 & 3.4 & 0.8 & 3.6 & - & 8.0 \\
\hline
\end{tabular}

The values in italic are the calculation based on the values that are not in italic

fabric group (KF13), resulting in the presence of doubleglazed layers (Fig. 7d).

\section{Composition}

All samples, regardless of their ware types and fabric groups, are lead glazes, with the majority having $\mathrm{PbO}$ concentrations over $50 \mathrm{wt} \%$ (Table 4). Lower $\mathrm{PbO}$ concentration is detected in the glaze of the painted glazed samples of the Micaceous Group (KF08, KF09, PS12, PS13, PS14, PS15, PS16) and the green plain glazed samples of the Mixed Carbonate Group
(AG18, KF10). These samples also have higher values of alumina, alkali, and alkaline earth oxides in the glaze (Fig. 8). The higher concentration of these oxides in the painted glazed samples was likely caused by an interaction with the clay-based paint, as revealed by the analysis of the paint of the biscuit-fired samples (PS17, PS18), resulting in the formation of wollastonite (dark, equant microcrystallites) and lead-feldspar (needle-like microcrystallites) in the painted areas. For AG18 and KF10, there is a gradual decrease in $\mathrm{MgO}, \mathrm{Al}_{2} \mathrm{O}_{3}, \mathrm{CaO}$ and $\mathrm{Fe}_{2} \mathrm{O}_{3}$ and increase of $\mathrm{PbO}$ concentration from the ceramic-glaze interface to the glaze margin 
(Supplementary Fig. 1). This compositional change, coupled with the thick interaction layer, suggests that the glaze was applied to an unfired ceramic body, stimulating the partial absorption of ceramic material into the glaze.

In terms of glaze colourants, the green glaze is coloured by $\mathrm{CuO}$, whereas most yellow and brown glazes have higher $\mathrm{Fe}_{2} \mathrm{O}_{3}$ concentration. Low $\mathrm{SnO}_{2}$ concentration $(<1.0 \mathrm{wt} \%)$ is detected in PS13, PS16, PT04, PT11, PT14 and PT21, present as bright microcrystallites rich in $\mathrm{PbO}$ and $\mathrm{SnO}_{2}$. Judging from their shape and rare occurrence, it is likely that the $\mathrm{SnO}_{2}$ was incorporated as impurities associated with the flux. We have previously argued that Roman lead pipes and solders might have been used as flux for the glaze as natural lead ores are rare in Cyprus (Ting et al. 2019; see also Segal 2015; Wyttenbach and Schubiger 1973). Around $2.0 \mathrm{wt} \%$ of $\mathrm{Sb}_{2} \mathrm{O}_{5}$ is present in the plain glazed samples of the Mixed Carbonate Group (KF10, KF13), which contain bright microparticles rich in $\mathrm{PbO}$ and $\mathrm{Sb}_{2} \mathrm{O}_{5}$, leading to an intense yellow glaze of KF13. It is not clear whether the lead antimonate was included intentionally to colour the glaze of KF10. The brown glaze seen in the plain glazed samples (AG05, AG10) and the slip-painted samples (PS09, PS10, PS11) of the Mixed Carbonate Group and the white glaze seen in the white-slipped samples of the Micaceous (AG19, AG20, VS04) and Mixed Carbonate Groups (AG06) were created through the application of transparent lead glaze over an ironrich brown slip and quartz-laden white slip, respectively. Analysis of the painted and unpainted areas of painted glazed samples of the Micaceous Group (PS14, PS16) shows that a transparent glaze was also used to cover the painted glazed samples, but the interaction with the underlying paint resulted in the transferal of the oxides used as colourants $\left(\mathrm{Fe}_{2} \mathrm{O}_{3}\right.$ and $\left.\mathrm{CuO}\right)$ from the paint to the glaze.

By removing the oxides relating to the flux and colourants from the glaze composition, and plotting the renormalised glaze and associated ceramic body or slip composition (Hurst and Freestone 1996; Walton and Tite 2010) (Supplementary Fig. 2), the Micaceous Group samples fall on the unity slope line, whereas the Mixed Carbonate Group samples deviate slightly from it. In contrast, the Amphibole-Serpentine Group samples do not fall on the unity slope line. Such patterning suggests that lead oxide was applied directly to the surface of the vessels of the Micaceous and some vessels of the Mixed Carbonate Groups to form the glaze, while a lead-silica mixture was used to make the glaze belonging to the Amphibole-Serpentine Group.

\section{Discussion}

\section{Provenance determination of the compositional groups}

The mineralogy of the three fabric groups is consistent with the geology of the Paphos, Famagusta and Lapithos regions, respectively, which are hypothesised to have been the main locations where the Cypriot glazed ware productions took place based on the results of stylistic analysis (du Plat Taylor and Megaw 1951; Papanikola-Bakirtzi 1989, 1996, 2012; Vallauri and François 2010; von Wartburg 1997; Waksman and von Wartburg 2006). The Amphibole-Serpentine Group represents the production in Paphos at the western tip of the island, where serpentine is one of the main lithologies of the igneous and sedimentary rocks of the Mamonia Formation (Hadjistavrinou and Afrodisis 1977; Robertson and Woodcock 1979). The provenance of this fabric group is further confirmed by its similarity with the mineralogical description of the local production of Late Hellenistic colour-coated pottery at Nea Paphos, which was established through the comparison with the sediments collected along the Ezousa River (Marzec et al. 2019). The dominance of biotite, quartz and limestone of the Micaceous Group aligns with the geology of the Lapithos region, the potential provenance of this fabric. Situated at the northern coast, Lapithos is underlain by sediments from the Kyrenia Range, comprising marbles and limestones of the Hilarion Formation and metamorphic rocks of Troodos Pillow Lavas. Lapithos is known to have been involved in pottery production from Bronze Age until modern times. Whereas the recipes for the Bronze Age pottery are yet to be determined as part of ongoing research by Dikomitou-Eliadou (2019), the mineralogy of the Micaceous Group seems to be consistent with the description of the Lapithos productions characterised by Constantinou and Panayides (2019) drawing references to ethnographic and geological records. The micritic texture and the presence of different kinds of carbonate inclusions of the Mixed Carbonate Group point to the Famagusta region as its possible origin. Sandy marls, calcareous sands and bioclastic limestones of the Athalassa Formation cover the eastern coast where Famagusta is located (Bear 1963).

\section{Reconstruction of technical practices of different productions}

\section{Paphos production}

The glazed wares designated as the Paphos production, which include slip-painted, plain glazed, sgraffito and sgraffito with slip-painted decoration, are dated to the thirteenth century CE. These vessels were all made using the same recipes of the ceramic body, paint, slip and glaze and following the same production sequence. Local clay was procured to form the ceramic body, which was then covered with white paint or slip. The paint was made of alumina-rich clay with little to no inclusions, whereas the slip was a mixture of alumina-rich clay and fine-grained quartz. The surface of sgraffito was further incised to expose the ceramic body underneath. All painted and slipped wares were fired before the glaze 


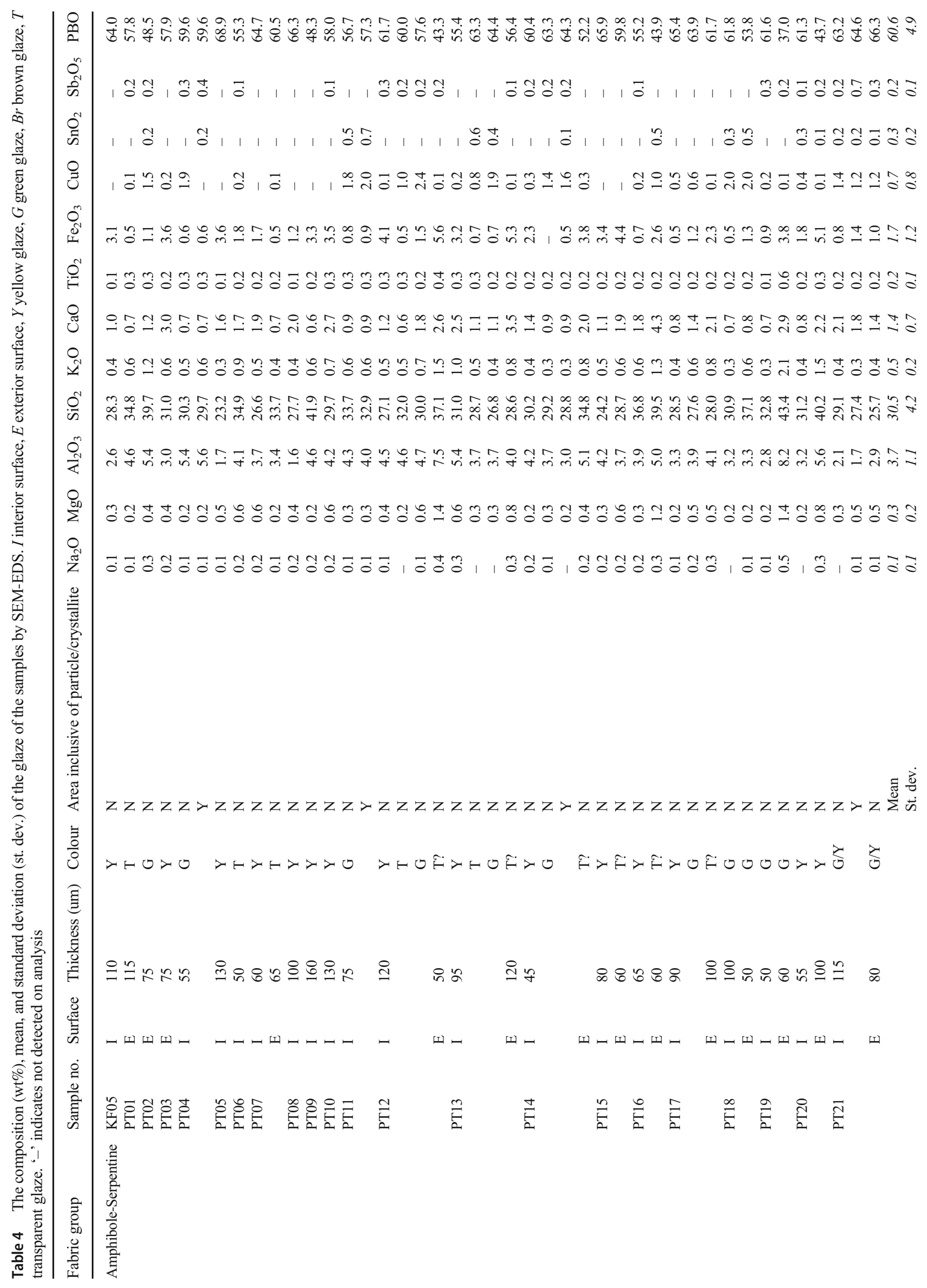




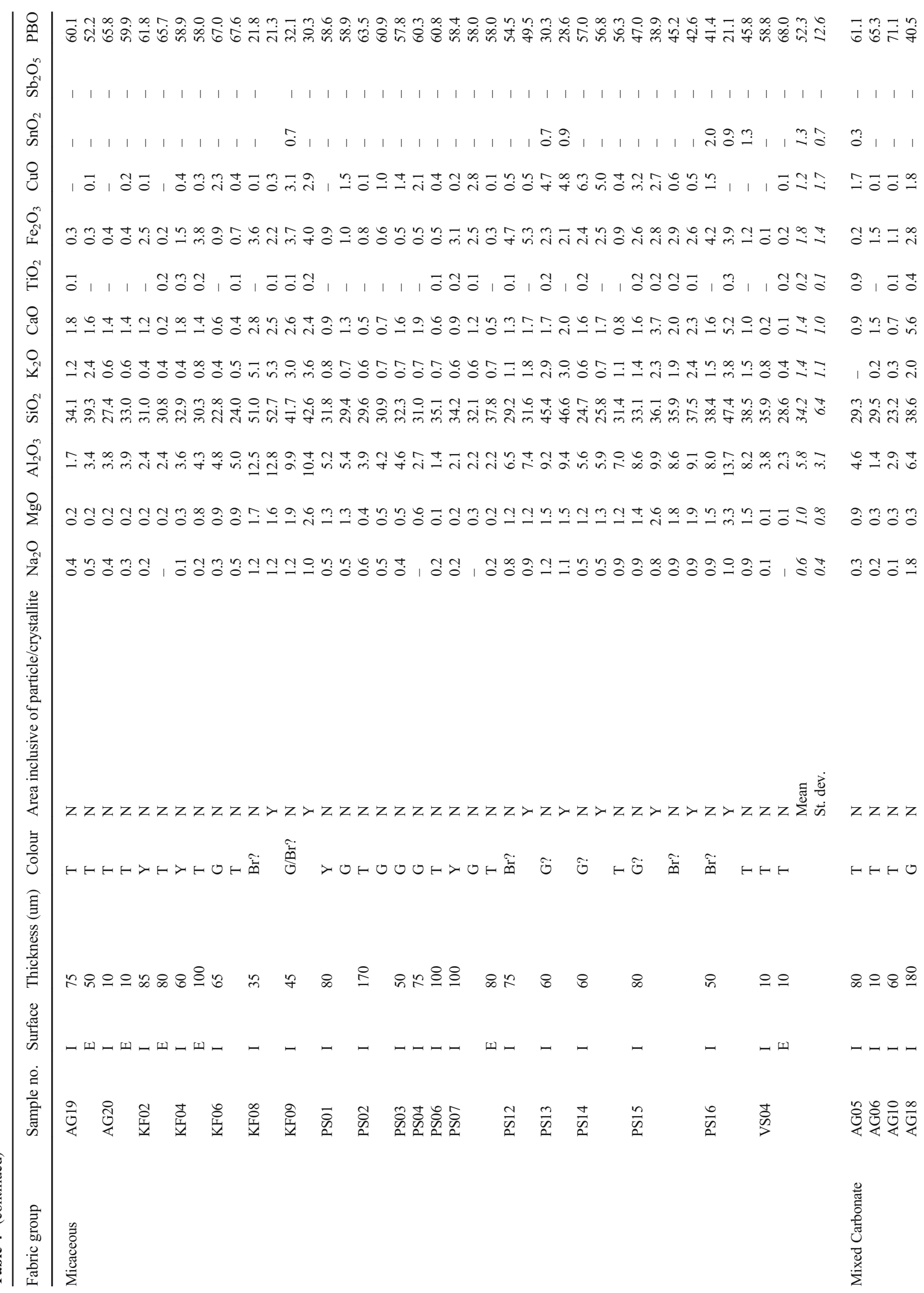


application, which were subjected to a second firing, as indicated by the thin interaction layer between the glaze and slip or ceramic body. The glaze was a mixture of lead oxide and silica, coloured by copper and iron oxides.

\section{Famagusta production}

The earliest evidence of the Famagusta production in this study are the plain glazed wares dated to the thirteenth to fourteenth centuries, which exhibit different technical practices. The green glaze was applied to an unfired, unslipped ceramic body, resulting in a thick interaction layer, and the chemical contribution of the ceramic body to the glaze. For the brown plain glazed wares, the ceramic body was covered with an iron-rich clay slip, which was fired before applying a layer of transparent lead glaze. This technique of covering the ceramic body with coloured slip and transparent glaze was also used to make the slip-painted wares dated to the fourteenth to fifteenth centuries. The slipped body was further decorated with white paint, which was made of alumina-rich clay and coarse-grained quartz.

The Famagusta production appears to have continued during the sixteenth and seventeenth centuries, with new, more diverse technical practices being introduced to make sgraffito, white-slipped and plain glazed wares. The slip of the sgraffito was made of alumina-rich clay with a few apatite inclusions and no quartz. The interior and exterior surfaces of the sgraffito were fully covered with white slip and coloured glaze rather than covering only the interior surface with slip and using coloured glazes to create splash decoration, as typical of other productions. It was also during this phase that the use of quartz-laden slip is recorded in the white-slipped ware. This production is further distinguished by the use of lead antimonate as colourant to create an intense yellow glaze for the plain glazed ware, which was not seen in other Cypriot productions.

\section{Lapithos production}

The glazed wares identified as Lapithos production fall into two broad phases. The early phase is dominated by sgraffito, dated between the fourteenth and sixteenth centuries. Although the production sequence displayed by the sgraffito was similar to that of the Paphos production, variation exists in the slip and glaze preparation method. Alumina-rich or calcareous clays mixed with quartz of varying shapes, sizes and abundance were used to make the slip, suggesting the coexistence of different potting groups in Lapithos. The glaze was formed by applying lead oxide directly to the fired ceramic body, as the renormalised glaze composition after removing the lead oxide value is similar to the underlying slip composition. 
a

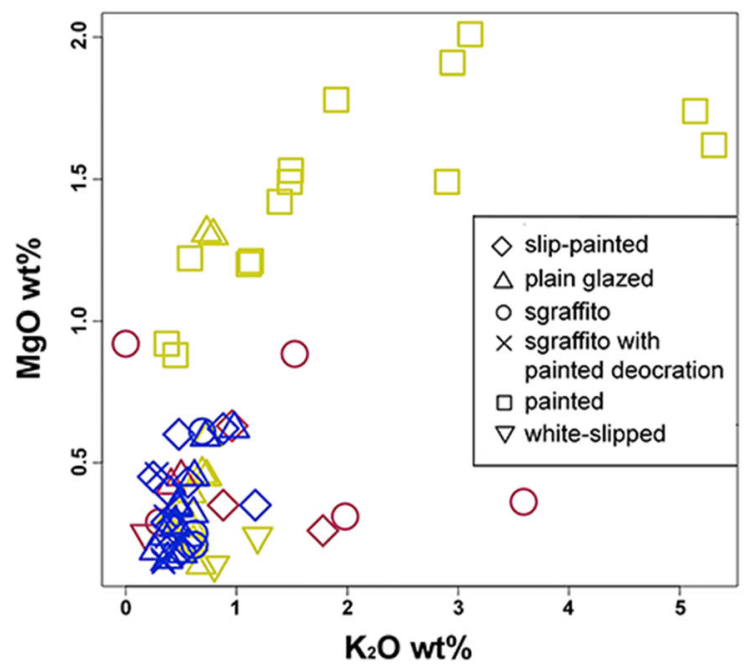

Fig. 8 Biplots showing that the glaze of the painted samples of the Micaceous Group (KF08-09, PS12-16) and the plain glazed samples of the Mixed Carbonate Group (AG18, KF10) deviate from other samples by having higher $\mathbf{a} \mathrm{MgO}$ and $\mathrm{K}_{2} \mathrm{O}$ concentration, and $\mathbf{b} \mathrm{Al}_{2} \mathrm{O}_{3}$ and $\mathrm{CaO}$

Technological change occurred during the sixteenth to seventeenth centuries, evidenced by the introduction of painted glazed ware. Incision and splashing coloured glazes, which were commonly used to decorate sgraffito, were replaced by painting. The paint was a mixture of iron or copper oxideenriched clay and lead oxide, different from the paint of the slip-painted ware of the Paphos and Famagusta productions. The vessels were first fired, followed by the painting of precise patterns on their interior surface and the application of a layer of transparent glaze. Such order of paint and glaze application is confirmed by the identification of the growth of the newly formed wollastonite and lead-feldspar microcrystallites specifically in the areas where the painted decorations were present. Despite the shift in decorative technique, the glaze preparation method remained constant, in which lead oxide rather than a lead-silica mixture was used.

\section{The developments of glazed ware productions in medieval and post-medieval Cyprus}

Three major observations emerge by comparing the three productions. First, there is little overlap in technological repertoires and trajectories among them. Second, over time, greater variety of technical practices appear to have developed in the Famagusta and Lapithos productions. Third, while the Paphos production was a short-lived one, the Lapithos and Famagusta productions remained active for a much longer period, and underwent significant changes during the sixteenth and seventeenth centuries. We argue that these developments are linked to the socio-political and economic developments in Cyprus and the broader eastern Mediterranean of the time. b

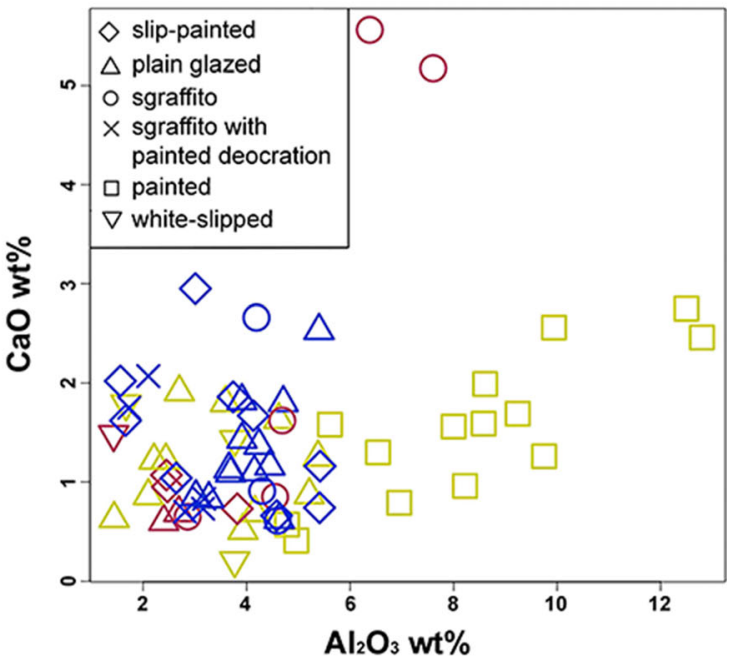

concentration. The blue samples represent the Amphibole-Serpentine Group (Paphos production), yellow samples of the Micaceous Group (Lapithos production), and red samples of the Mixed Carbonate Group (Famagusta production)

Glazed ware production in Cyprus began in the thirteenth century, stimulated by the establishment of Frankish rule on the island (Cook 2014; von Wartburg 1997). The Franks' involvement in the Crusader campaigns created demand for Cypriot goods, with ports such as Limassol and Paphos functioning as stopovers for pilgrims to refill supplies on their way to the Levant (Coureas 1995, 2005; Stern 2012). Accordingly, the vast majority of glazed wares that are stylistically typical of the Paphos production were recovered in the Levant (Boaz 1999; Stern 2014), with only a few being found in Cyprus; pointing to a targeted export to the Crusader States. This may explain why the Paphos production declined shortly after the collapse of the Crusader States in the East, following the fall of Acre in 1291 (Cook 2014; von Wartburg 1997).

Despite the loss of the Crusaders markets, production continued in the Famagusta and Lapithos region, with their products largely circulating within Cyprus. The collapse of the Crusader entities triggered the relocation of trading outposts from the Levant to Cyprus by the Western powers (Ashtor 1983; Edbury 1991), enabling its transformation to a regional and international trading hub (Coureas 2005; Day 2002; Edbury 1999; Özkutlu 2014). Historical records highlighted the pivotal role played by Famagusta in the pan-Mediterranean trade during the thirteenth to fifteenth centuries (Edbury 1999; Jacoby 1989; Philips 1995), whereas another trading settlement is said to have been built in Lapithos and its adjacent port in Kyrenia (Jacoby 1977). Such a surge in commercial activities not only attracted merchants from the West, particularly the Genoese and Venetians, but also offered opportunities for local populations to get involved in trade and related activities. All these contributed to an overall elevation in wealth and social status within the Cypriot society, generating a local demand for glazed wares. 
The technical practices used by the Famagusta and Lapithos potters deviated from the Paphos ones, but the ware types made by the three productions were broadly similar, represented by slip-painted, plain glaze and sgraffito. These ware types bear close stylistic similarities with contemporaneous ceramics from the Levant, specifically evident in the Paphos and early Lapithos sgraffito, and Port Saint Symeon Ware from the Frankish Principality of Antioch (Sanders 2003; Stern 2012; Vionis 2017). This may be explained on the basis of the intensive contacts between Cyprus and the Levant first through the trading of the Paphos products in the thirteenth century. Later on, after the fall of Acre, this influence in styles and technology accelerated after Christian populations fled from Syria and Palestine to Cyprus (Jacoby 2014), promoting the transferral of different bodies of technical knowledge and trends to the island, as evident in the technological variations of the Famagusta and Lapithos productions. However, a full reconstruction of technical practices of different productions in the neighbouring regions as such is still missing; thus, it is difficult to pinpoint exactly where the influences might have derived from.

Interestingly, little similarity exists between the technical practices used by the Famagusta and Lapithos productions, possibly because they were sponsored by competing merchant groups. Being the most prominent foreign merchants operating in Cyprus, the Genoese were granted the exclusive right to trade in Famagusta, while the Venetians had stronger influence in Kyrenia and other ports (Grivaud 1993; Özkutlu 2014); both are known to have modified the economic landscape of the regions where they settled (García Porras and Fábregas García 2010). Given the constant vying for power between the Genoese and Venetians, some kind of measures might have been implemented to prevent the exchange of technical knowledge between potters in Famagusta and Lapithos. Surviving notarial deeds recorded that novices were tied to long-term apprenticeships to learn crafts such as ship-building and woodworking (Coureas 2014), and it is reasonable to assume that similar schemes were applied to glazed ware production, too.

The changes we identify in the Famagusta and Lapithos productions around the sixteenth and seventeenth centuries were not only limited to the technical practices, but also to the ware types produced (i.e. white-slipped and painted glazed wares), which we believe was stimulated by the Ottoman occupation of the island following the final capture of Famagusta in 1571. The initial years of Ottoman rule saw the expulsion of the Venetian rulers and the Western landholding classes, and the appointment of a new non-Western ruling class (Erdoğru 1997; Given 2000). In addition to restructuring the political order, drastic changes occurred to the socio-economic organisation. The reformation of the fiscal system, in particular, allowed agricultural taxes to be paid in cash rather than in kind, providing means for rural communities to accumulate wealth (Quataert 2000). As ceramic research in other regions under Ottoman rule has illustrated, pottery produced locally lost the refinement of shape and decoration that characterised ceramics of the preceding late medieval period, but increased in volume, rendering it affordable for the less-affluent classes (Vionis 2016; Walker 2009).

The presence of Ottoman rule in Cyprus also induced forced migration of people, including artisans, from mainland Anatolia. It is argued that incoming artisans took over certain areas of craft production (Erdoğru 1997), but their involvement was not particularly obvious in pottery production, at least not among the glazed wares under study. Whereas the use of lead antimonate as glaze colourant by the Famagusta production points to the possible exchange of influence or raw materials from Anatolia (Constantinescu et al. 2014), other technical aspects of the sixteenth- and seventeenth-century Famagusta and Lapithos productions seem to have had little in common with Iznik and Miletus wares, the better-known examples of Ottoman pottery (Burlot et al. 2020; Henderson 1989; Paynter et al. 2004; Tite et al. 2016). In fact, some technical practices exhibited certain extents of continuity, as seen in the glaze preparation method of the Lapithos production, suggesting that technological changes occurred gradually by mixing local practices with new elements, possibly inspired by external contacts.

\section{Conclusion}

Our study represents the first systematic characterisation of local glazed ware productions across Cyprus. We identify three main regions-Paphos, Famagusta, and Lapithoswhere production took place. Interpreting the results of macroscopic, petrographic and SEM-EDS analyses in combination with the chaine opératoire reveals that each production had distinctive sets of technical practices, and that these practices changed through time. We argue that the changes in technology and craft organisation were first linked to the rise and fall of the Crusader territories in the East, the emergence of local demand as a result of an intensification of commercial activities and finally the restructuring of socio-political foundations brought by the Ottoman rule.

These findings have important implications beyond their regional archaeological significance. We have painted a differentiated picture of the nature and characteristics of nonopaque glazed ware productions from the earlier assumptions, in which they are described to be technologically stagnant and unsusceptible to broader socio-economic developments. Whereas it is likely that local production centres procured the same type of raw materials over time, it does not necessarily imply that how the raw materials were prepared and the steps involved in making the vessels remained the same. We have further demonstrated that the emergence of local productions was stimulated by a wide array of factors, largely context-specific. These new observations are made evident owing to the new research framework developed by our study, 
highlighting the importance of considering the whole production sequence rather than focusing on one or two technological aspects. This framework, which provides a structured way to organise and compare data, can be readily applied to identify other local productions in the eastern Mediterranean. Together, this will unlock a host of new evidence, enabling us to explore the dynamics of socio-cultural interactions that contributed to making glazed wares an essential part of our daily lives since medieval times.

Supplementary Information The online version contains supplementary material available at https://doi.org/10.1007/s12520-020-01270-4.

Acknowledgements We are grateful to the Department of Antiquities of Cyprus for granting us permission to study and sample the materials for analysis. We are equally grateful to the participants of the field projects from which our materials were derived, specifically Craig Barker, Holly Cook, Veronique François, Smadar Gabrieli, Doria Nicolaou, Giorgos Papantoniou, Despina Pilides, and Lucy Vallauri. We would also like to thank Tom Gregory at the UCL Wolfson Archaeological Sciences Laboratories for his technical support, and UCL Qatar for facilitating access to the JEOL SEM-EDS system in Doha; UCL Qatar was a department of UCL established in cooperation with Qatar Museums at Education City, generously funded through Qatar Foundation.

Authors' contributions All authors contributed to the research presented in the paper in accordance with their specialisations, and to the writing and editing of the paper.

Funding This research was carried out as part of the Marie SkłodowskaCurie Actions Individual Fellowship 'GLAZE', which was based at the University of Cyprus and including a secondment to the UCL Institute of Archaeology, funded by the European Commission Horizon 2020 framework (H2020-MSCA-IF-2016; grant no. 750904).

Data availability All data are included in the paper.

\section{Compliance with ethical standards}

Conflict of interest The authors declare that they have no conflicts of interest.

\section{Code availability Not applicable}

Open Access This article is licensed under a Creative Commons Attribution 4.0 International License, which permits use, sharing, adaptation, distribution and reproduction in any medium or format, as long as you give appropriate credit to the original author(s) and the source, provide a link to the Creative Commons licence, and indicate if changes were made. The images or other third party material in this article are included in the article's Creative Commons licence, unless indicated otherwise in a credit line to the material. If material is not included in the article's Creative Commons licence and your intended use is not permitted by statutory regulation or exceeds the permitted use, you will need to obtain permission directly from the copyright holder. To view a copy of this licence, visit http://creativecommons.org/licenses/by/4.0/.

\section{References}

Adlington LW (2017) The Corning archaeological reference glasses: new values for 'old' compositions. Papers from the Institute of Archaeology 27:1-8. https://doi.org/10.5334/pia-515

Armstrong P, Hatcher H, Tite M (1997) Changes in Byzantine glazing technology from the 9th to 13th centuries. In: Démians DG (ed) La Céramique Médiévale en Méditerrnée: Actes du Vle congrés l'AIECM2 Aix-en-Provence (13-18 Novembre 1995). Narration Éditions, Aix-en-Provence, pp 225-229

Ashtor E (1983) Levant trade in the later Middle Ages. Princeton University Press, Princeton

Barker C (2016) The theatre precinct of Nea Paphos (Fabrika): recent excavations by the Australian mission. In: Balandier C (ed) Nea Paphos: Fondation et Développement Urbanistique d'une Ville Chypriote de 1'Antiquité à nos Jours. Études Archéologiques, Historiques et Patrimoniales. Ausonius, Bordeaux, pp 91-104

Bear LM (1963) The mineral resources and mining industry of Cyprus. Bulletin No. 1. Geological Survey Department, Ministry of Commerce and Industry, Nicosia

Boaz AJ (1999) Crusader Archaeology: The Material Culture of the Latin East. Routledge, London

Burlot J, Waksman Y, Bellot-Gurlet L, Simsek G (2020) 'Miletus Ware': an early Ottoman marker of a ceramic technology transition in western Anatolia. J Arch Sci: Reps 29(102073):1-11. https://doi.org/10. 1016/j.jasrep.2019.102073

Charalambous AC (2014) Cypriot medieval glazed pottery: a study of provenance and manufacture. In: Papanikola-Bakirtzi D, Coureas N (eds) Cypriot medieval ceramics: reconsiderations and new perspectives. The A.G. Leventis Foundation, Nicosia, pp 279-298

Charalambous AC, Sakalis AJ, Kantiranis NA, Papadopoulou LC, Tsirliganis C, Stratis JA (2010) Cypriot Byzantine glazed pottery: the study of Paphos workshops. Archaeometry 52:628-643. https:// doi.org/10.1111/j.1475-4754.2009.00502.x

Charalambous A, Charalambous E, Violaris Y, Kantiranis N, Stratis J (2012) Study of glazed ceramics from Lapithos and Nicosia by Xray micro-fluorescence ( $\mu-\mathrm{XRF})$ and X-ray diffraction (XRD). Report of the Department of Antiquities, Cyprus 2010:537-550

Constantinescu B, Cristea-Stan D, Kovács I, Szökefalvi-Nagy Z (2014) External milli-beam PIXE analysis of the mineral pigments of glazed Iznik (Turkey) ceramics. Periodico di Mineralogia 83:159 169. https://doi.org/10.2451/2013PM0009

Constantinou G, Panayides I (2019) The geological and physicogeographical environment of Lapithos and the materials for local ceramic production. In: Papanikola-Bakirtzi D (ed) Ceramic Art from the Soil of Lapithos. Leventis Municipal Museum of Nicosia and Lapithos Municipality, Nicosia, pp 17-39

Cook HKA (2004) The Hellenistic theatre at Nea Paphos and its medieval players. Med Arch 17:275-285

Cook H (2014) From boom to bust: the impact of the Crusades upon the glazed pottery Paphos, Cyprus, during the thirteenth and fourteenth centuries A.D. From the Theatre Workshop perspective. In: Papanikola-Bakirtzi D, Coureas N (eds) Cypriot medieval ceramics: reconsiderations and new perspectives. The A.G. Leventis Foundation, Nicosia, pp 29-44

Cook HKA, Green JR (2002) Medieval glazed wares from the Theatre site at Nea Paphos, Cyprus: preliminary report. Report of the Department of Antiquities, Cyprus, pp 413-426

Coureas N (1995) Western merchants in the ports of Cyprus up to 1291. In: Karageorghis V, Michaelides D (eds) Cyprus and the Sea. University of Cyprus, Nicosia, pp 255-261

Coureas N (2005) Economy. In: Nicolaou-Konnari A, Schabel C (eds) Cyprus, Society and Culture 1191-1394. Brill, Leiden, pp 103-156

Coureas N (2014) Apprentice artisans and craftsmen in Famagusta in the notarial deeds of Lamberto di Sambuceto and Giovanni da Rocha, 
1296-1310. In: Walsh M, Kiss T, Coureas N (eds) The harbour of all this sea and realm: Crusader to Venetian Famagusta. Central European University Press, Budapest, pp 69-75

Day J (2002) The Levant trade in the Middle Ages. In: Laiou AE (ed) The economic history of Byzantium: from the seventh through the fifteenth century. Dumbarton Oaks Library Collection, Washington D.C., pp $807-814$

Dikomitou-Eliadou M (2019) A preliminary compositional study of Early and Middle Bronze Age pottery from Lapithos. In: PapanikolaBakirtzi D (ed) Ceramic art from the soil of Lapithos. Leventis Municipal Museum of Nicosia and Lapithos Municipality, Nicosia, pp 57-75

Edbury P (1991) The kingdom of Cyprus and the crusades, 1191-1374. Cambridge University Press, Cambridge

Edbury P (1999) Kingdoms of the Crusaders: from Jerusalem to Cyprus. Ashgate, Aldershot

Erdoğru MA (1997) The servants and Venetian interest in Ottoman Cyprus in the late sixteenth and the early seventeenth centuries. Quaderni di Studi Arabi. Suppl. no. 15:97-120

François V, Vallauri L (2001) Production et consumation de céramiques à Potamia (Chypre) de l'époque franque à l'époque ottomane. Bulletin de Correspondance Hellénique 125:523-546. https://doi. org/10.3406/bch.2001.7151

François V, Vallauri L (2014) Ceramics from Potamia-Agios Sozomenos: new archaeological data on the ceramic production and trade in Cyprus. In: Papanikola-Bakirtzi D, Coureas N (eds) Cypriot medieval ceramics: Reconsiderations and new perspectives. The A.G. Leventis Foundation, Nicosia, pp 45-55

du Plat-Taylor J, Megaw AHS (1951) Cypriot medieval glazed pottery notes for a preliminary classification. Reports of Department of Antiquities Cyprus 1939:1-13

García Porras A, Fábregas García A (2010) Genoese trade networks in the southern Iberian Peninsula: Trade, transmission of technical knowledge and economic interactions. Mediterranean Historical Review 25:35-51. https://doi.org/10.1080/09518967.2020.494097

Given M (2000) Agriculture, settlement and landscape in Ottoman Cyprus. Levant 32:215-236

Gosselain OP (1998) Social and technical identity in a clay crystal ball. In: Stark MT (ed) The archaeology of social boundaries. The Smithsonian Institution, Washington D.C., pp 78-106

Green JR, Barker C, Gabrieli S (2011) Fabrika: an ancient theatre of Nea Paphos. The A.G, Leventis Foundation, Nicosia

Green JR, Gabrieli RS, Cook HKA, Stern EJ, McCall B, Lazer E (2014) Paphos 8 August 1303: Snapshot of Destruction. The A.G, Leventis Foundation, Nicosia

Grivaud G (1993) Sur le commerce Chypriote de l'époque Latine. In: Bryer AAM, Georghallides GS (eds) The sweet land of Cyprus, papers given at the Twenty-fifth Jubilee Spring Symposium of Byzantine Studies, Birmingham, March 1991. Cyprus Research Centre for the Society for the Promotion of Byzantine Studies, Nicosia, pp 133-145

Hadjistavrinou Y, Afrodisis S (1977) Geology and hydrogeology of the Paphos region. In: Hadjistavrinou Y (ed) Bulletin no. 7 of the Geological Survey Department. Ministry of Agriculture and Natural Resources, Nicosia, pp 1-44

Henderson J (1989) Iznik ceramics: a technical examination. In: Atasoy N, Raby J (eds) Iznik - the pottery of Ottoman Turkey. Alexandria Press, London, pp 65-87

Hunt D (2014) Medieval Cyprus 1191-1571. In: Papanikola-Bakirtzi D (ed) Colours of Medieval Cyprus. The A.G. Leventis Foundation, Nicosia, pp 19-33

Hurst D, Freestone I (1996) Lead glazing technique from a medieval kiln site at Hanley Swan, Worcestershire. Med Ceram 20:13-18

Jacoby D (1989) The rise of a new emporium in the eastern Mediterranean: Famagusta in the late thirteenth century. Variorum, Northampton
Jacoby D (1977) Citoyens, sujets et protégés de Venise et de Gênes en Chypre du XIIIe au XVe siècles. Byzantinische Forschungen 5: $159-188$

Jacoby D (2014) Refugees from Acre in Famagusta around 1300. In: Walsh M, Kiss T, Coureas M (eds) The harbour of all this sea and realm: Crusader to Venetian Famagusta. Central European University Press, Budapest, pp 53-67

Lécuyer N, Grivaud G, Michaelides D, Nicolaïdes A, Amouric H, Decock L, Devillers B, François V, Hadjichristofi F, Loiseau M, Bernard S, Vallauri L (2002) Potamia-Agios Sozomenos (Chypre). La constitution des paysages dans l'Orient Médiéval. Bulletin de Correspondance Hellénique 126:598-614

Lécuyer N, Michaelides D (2004) Archaeological survey at PotamiaAyios Sozomenos. British School at Athens Studies 11:139-149

Lemonnier P (1992) Elements for an anthropology of technology. The University of Michigan Press, Ann Arbor

Marzec E, Kiriatzi E, Müller NS, Hein A (2019) An integrated typological, technological and provenance investigation of Late Hellenistic colour-coated pottery from Nea Paphos. Cyprus. Arch Anth Sci 11: 4103-4122. https://doi.org/10.1007/s12520-019-00786-8

Mason R (1997) Medieval Syrian lustre-painted and associated wares: typology in a multidisciplinary study. Levant 29:169-200. https:// doi.org/10.1179/lev.1997.29.1.169

Mason R, Tite MS (1997) The beginnings of tin-opacification of pottery glazes. Archaeometry 39:41-58. https://doi.org/10.1111/j.14754754.1997.tb00789.x

Matin M, Tite M, Watson O (2018) On the origins of tin-opacified ceramic glazes: new evidence from early Islamic Egypt, the Levant, Mesopotamia, Iran, and Central Asia. J Arch Sci 97:42-66. https:// doi.org/10.1016/j.jas.2018.06.011

Matthews AJ, Woods AJ, Oliver C (1991) Spots before the eyes: new comparison charts for visual percentage estimation in archaeological material. In: Middleton A, Freestone I (eds) Recent developments in ceramic. British Museum Research Laboratory, London, pp $211-$ 264

Molera J, Martines Ferreras V, Fusaro A, Gurt Esparraguera JM, Gaudenzi Asinelli M, Pidaev SR, Pradell T (2020) Islamic glazed wares from ancient Termez (south Uzbekistan). Raw materials and techniques. J Arch Sci: Reps 29:102169:1-11. https://doi.org/10. 1016/j.jasrep.2019.102169

Özkutlu S (2014) Medieval Famagusta: socio-economic and sociocultural dynamics (13th to 15 th centuries). Dissertation, University of Birmingham

Palamara E, Zacharias M, Xanthopoulou M, Kasztovszky Z, Kovács I, Palles D, Kamitsos EI (2016) Technology issues of Byzantine glazed pottery from Corinth, Greece. J Microchem 129:137-150. https://doi.org/10.1016/j.microc.2016.06.008

Papanikola-Bakirtzi D (1989) Medieval pottery from Enkomi, Famagusta. In: Déroche V, Spieser J-M (eds) Recherches sur la Céramique Byzantine, vol 18, pp 233-246

Papanikola-Bakirtzi D (1996) Medieval glazed pottery from Cyprus: the workshops of Paphos and Lapithos. The A.G. Leventis Foundation, Thessaloniki

Papanikola-Bakirtzi D (2004) Colours of Medieval Cyprus through the Medieval Ceramic Collection of the Leventis Municipal Museum of Nicosia. The Anastasios G. Leventis Foundation and The Leventis Municipal Museum, Nicosia

Papanikola-Bakirtzi D (2012) Colours of Medieval Cyprus. The A.G, Leventis Foundation, Nicosia

Papanikola-Bakirtzi D (2019) Ceramic art from the soil of Lapithos. Leventis Municipal Museum of Nicosia and Lapithos Municipality, Nicosia, pp 105-125

Papantoniou G, Vionis AK (2018) The river as an economic asset: settlement and society in the Xeros valley in Cyprus. Land 7(4):157. https://doi.org/10.3390/land7040157 
Paynter S, Okyar F, Wolf S, Tite MS (2004) The production of Iznik pottery - a reassessment. Archaeometry 46:421-447. https://doi.org/ 10.1111/j.1475-4754.2004.00166.x

Philips J (1995) The Latin East, 1098-1291. In: Riley-Smith J (ed) The Oxford Illustrated History of the Crusades. Oxford University Press, Oxford, pp 112-140

Pilides D (2003) Excavations at the Hill of Agios Georgios (PA.SY.D.Y.), Nicosia, 2002 season - preliminary report. Report of the Department of Antiquities, Cyprus:181-237

Pilides D, Hermon S, Amico N, Chamberlain M, d'Andrea A, Iannone G, Ronzino P (2010) The Hill of Agios Georgios, Nicosia: 3D analysis of an on-going archaeological excavation. In: Melero FJ, Cano P, Revelles J (ed) Fusion of cultures: abstracts of the XXXVIII conference on computer applications and quantitative methods in archaeology, pp 325-28

Pradell T, Molera J (2020) Ceramic technology. How to characterise ceramic glazes. Arch Anth Sci 12(189):1-28. https://doi.org/10. 1007/s12520-020-01136-9

Quataert D (2000) Consumption studies and the history of the Ottoman Empire, 1550-1922: an introduction. State University of New York, Albany

Robertson AHF, Woodcock NH (1979) Mamonia Complex, southwest Cyprus: evolution and emplacement of a Mesozoic continental margin. GSA Bulletin 90(7):651-665

Salinas E, Pradell T, Matin M, Tite M (2019) From tin- to antimonybased yellow opacifiers in the early Islamic Egyptian glazes: regional influences and ruling dynasties. J Arch Sci: Reps 26(101923):112. https://doi.org/10.1016/j/jasrep.2019.101923

Sanders GDR (2003) Recent developments in the chronology of Byzantine Corinth. In: Williams CK, Bookidis N (eds) Corinth XX: the centenary, 1896-1996. American School of Classical Studies at Athens, Princeton, pp 385-399

Segal I (2015) Chemical and isotopic study of lead-based objects from a Late Roman tomb on Sallah ed-Din Street, Jerusalem. Atiqot 80: $133-138$

Stern EJ (2012) Akko I: the 1991-1998 excavations. The Crusaderperiod pottery. Part 1: text. Israel Antiquities Authority, Jerusalem

Stern EJ (2014) The Paphos glazed wares: distribution and consumption in the Latin Kingdom of Jerusalem. In: Papanikola-Bakirtzi D, Coureas N (eds) Cypriot medieval ceramics: reconsiderations and new perspectives. The A.G. Leventis Foundation, Nicosia, pp 61-76

Ting C, Vionis A, Rehren T, Kassianidou V, Cook H, Barker B (2019) The beginning of glazed ware production in late medieval Cyprus. $\mathrm{J}$ Arch Sci: Rep 27(101963):1-13. https://doi.org/10.1016/j.jasrep. 2019.101963

Tite MS, Shortland AJ, Schibille N, Degryse P (2016) New data on the soda flux used in the production of Iznik glazes and Byzantine glasses. Archaeometry 58:57-67. https://doi.org/10.1111/arcm. 12156

Tite MS, Watson O, Pradell T, Matin M, Molina G, Domoney K, Bouquillon A (2015) Revisiting the beginnings of tin-opacified
Islamic glazes. J Arch Sci 57:80-91. https://doi.org/10.1016/j.jas. 2015.02.005

Vallauri L (2004) Céramiques en usage à Potamia-Agios Sozomenos de l'époque médiévale à l'époque ottoman: nouvelles données. Cahiers du Centre d'Études Chypriotes 34:223-238

Vallauri L, François V (2010) Famagouste: indices d'une production de vaisselle à l'époque vénitienne. Cahiers du Centre d'Études Chypriotes 40:295-310

Vionis AK (2016) A boom-bust cycle in Ottoman Greece and the ceramic legacy of two Boeotian villages. J Greek Arch 1:353-384

Vionis AK (2017) The Byzantine to Early Modern pottery from Thespiai. In: Bintliff JL, Farinetti E, Slapak B, Snodgrass AM (eds) Boeotia Project, Volume II: the city of Thespiai. Survey at a complex urban site. McDonald Institute Monographs, Cambridge, pp 351-374

Vionis AK (2018) Settled and sacred landscapes of Cyprus: church and landscape in the Xeros valley during the Early Byzantine period. In: Horster M, Nicolaou D, Rogge S (eds) Church building in Cyprus (Fourth to Seventh Centuries). A mirror of intercultural contacts in the Eastern Mediterranean. Waxman Verlag, Münster, pp 45-70

von Wartburg M-L (1997) Lemba ware reconsidered. Report of the Department of Antiquities, Cyprus, pp 323-345

Waksman SY (2014) Archaeometric approaches to ceramic production and imports in medieval Cyprus. In: Papanikola-Bakirtzi D, Coureas $\mathrm{N}$ (eds) Cypriot medieval ceramics: reconsiderations and new perspectives. The A.G. Leventis Foundation, Nicosia, pp 257-278

Waksman Y, von Wartburg M-L (2006) 'Fine-sgraffito ware', 'Aegean ware', and other wares: new evidence for a major production of Byzantine ceramics. Reports of the Department of Antiquities Cyprus:368-388

Walker BJ (2009) Identifying the Late Islamic period ceramically: preliminary observations on Ottoman wares from Central and Northern Jordan. In: Walker BJ (ed) Reflections of empires: archaeological and ethnographic studies on the pottery of the Ottoman Levant. The American Schools of Oriental Research, Massachusetts, pp 37-65

Walton MS, Tite MS (2010) Production technology of Roman leadglazed pottery and its continuance into late antiquity. Archaeometry 52:733-759. https://doi.org/10.1111/j.1475-4754. 2009.00506.x

Watson O (2014) Revisiting Samarra: the rise of Islamic glazed pottery. In: Gonnella J, Abdellatif R, Struth S (eds) Beiträge zur Islamischen Kunst und Archäologie, vol 4, pp 125-144

White HE (2009) An investigation of production technologies of byzantine glazed pottery from Corinth, Greece in the 11th to 13th centuries. Dissertation, University of Sheffield

Wyttenbach A, Schubiger PA (1973) Trace element content of Roman lead by neutron activation analysis. Archaeometry 15:199-207. https://doi.org/10.1111/j.1475-4754.1973.tb00090.x

Publisher's note Springer Nature remains neutral with regard to jurisdictional claims in published maps and institutional affiliations. 